OXMAN, Nicolás. “Aspectos político-criminales y criminológicos de la criminalización de la posesión de pornografía infantil en Estados Unidos de Norteamérica".

Polit. crim. Vol. 6, № 12 (Diciembre 2011), Art. 2, pp. 252 - 294.

[http://www.politicacriminal.cl/Vol_06/n_12/Vol6N12A2.pdf]

\title{
Aspectos político-criminales y criminológicos de la criminalización de la posesión de pornografía infantil en Estados Unidos de Norteamérica*
}

\author{
Nicolás Oxman \\ Magíster en Derecho Penal \\ Universidad de Talca \\ Profesor de Derecho Penal \\ Universidad Santo Tomás \\ nicolasoxman@santotomas.cl
}

A la memoria de

Mario Garrido Montt

\section{Resumen}

En Estados Unidos de Norteamérica la ley describe la pornografía infantil como una forma de abuso y explotación sexual en que la imagen del niño envuelve una conducta sexual explícita y una seria amenaza para la salud física, mental, la seguridad y el bienestar de la infancia. Las imágenes reales (en oposición a las imágenes generadas digitalmente, así como las ilustraciones) de pornografía infantil son vistas como un registro permanente de un abuso sexual causado a la víctima, y su creación y distribución se considera un delito grave en el Código Federal de los Estados Unidos. La posibilidad de que sea usado con fines de acoso (grooming), se utiliza como justificación para la penalización de la pornografía infantil, así como para la criminalización de la creación, realización, distribución y posesión de pseudoimágenes elaboradas por computadora. De hecho, en los últimos años existe una gran atención pública en relación a los delincuentes poseedores de pornografía infantil, especialmente, con la aparición de Internet y la variedad de contenidos pornográficos que se encuentran disponibles. Un asunto importante es determinar si los poseedores de pornografía infantil son propensos a cometer un delito sexual que involucre contacto con un niño. Este artículo describe la evolución legislativa en los Estados Unidos y la literatura actual más importante que se conoce sobre el riesgo que un individuo que utilice Internet pueda cometer un delito de abuso o contacto sexual con menores.

\section{Palabras Clave}

Pornografía infantil, delitos de posesión, evaluación de riesgos.

\begin{abstract}
In the United States of America, child pornography is described in the law as a form of sexual abuse and exploitation in which the depiction of children engaging in sexually explicit conducts poses a serious threat to the physical and mental health, safety and well-
\end{abstract}


OXMAN, Nicolás. “Aspectos político-criminales y criminológicos de la criminalización de la posesión de pornografía infantil en Estados Unidos de Norteamérica”.

being of children. Real images (as opposed to computer generated images and drawings) of child pornography are seen as a permanent record of the victim's abuse, and its creation and distribution is considered a serious crime in the United States Federal Code. The possibility of such use for grooming purposes is often used as a justification for the criminalization of possession of child pornography as well as for the criminalization of the creation, execution, distribution and possession of computer generated pseudo-photographs. In fact, there has been a great deal of public attention to child pornography offenders in recent years, particularly with the emergence of the Internet and pornographic content that it has made available. A particularly salient question is whether child pornography offenders are likely to commit a sexual offense involving contact with a child. This paper describes the legislative development in the United States and most important current literature on what is known about the risk of individuals using the Internet to commit felonies of sexual abuse or sexual contact with minors.

\section{Keywords}

Child pornography, Possession offenses, Risk assessment

\section{Introducción}

Cada vez son más concluyentes y abundantes las declaraciones internacionales que se han establecido por los Estados pertenecientes a las Naciones Unidas con la finalidad de evidenciar su preocupación por la persecución y sanción de la pornografía infantil. Dentro del marco internacional, es posible encontrar no solo la Convención de Internacional de Derechos del Niño, creada por la resolución 44/25, de 20 de noviembre de 1989, de la Asamblea General de Naciones Unidas, sino que, también, el Protocolo facultativo de dicha Convención relativo a la venta de niños, la prostitución infantil y la utilización de niños en la pornografía, creado por la resolución 54/263, del 25 de mayo de 2000, de la Asamblea General de Naciones Unidas. ${ }^{1}$ En este instrumento internacional se establece, en lo que se refiere a la pornografía infantil, una definición en el art. $2^{\circ} \mathrm{c}$ ) donde se entiende por tal "toda representación, por cualquier medio, de un niño dedicado a actividades sexuales explícitas, reales o simuladas, o toda representación de las partes genitales de un niño con fines primordialmente sexuales". Junto a ello, el parágrafo tercero, apartado primero, letra c) declara que todo Estado parte deberá tipificar en su legislación penal "la producción, distribución, divulgación, exportación, oferta, venta o posesión, con los fines antes señalados de pornografía infantil, en el sentido en que se define en el artículo $2^{\circ}$ ". Ahora bien, en lo que respecta a las obligaciones asumidas para el cumplimiento del Protocolo y

\footnotetext{
* El presente trabajo corresponde, con algunas modificaciones menores, a la exposición de la defensa oral de mi tesis para optar al grado de Magíster en Derecho Penal de la Universidad de Talca, cuya dirección y orientación estuvo a cargo de la Prof. Mg. María Cecilia Ramírez, participando, además, en el tribunal que la calificó el Prof. Dr. Raúl Carnevali y el Prof. Dr. Eduardo Riggi.

${ }^{1}$ Este Protocolo es el resultado de "las conclusiones adoptadas en la Conferencia Internacional de lucha contra la pornografía infantil en Internet, celebrada en Viena en 1999; con anterioridad apareció el informe de la relatora especial de Naciones Unidas sobre la venta de niños, la prostitución infantil y la utilización de niños en la pornografía, de 13 de enero de 1998, y poco después su informe sobre idénticos temas, de 14 de enero del 2000". ORTS BERENGUER, Enrique; ROIG TORRES, Margarita, Delitos informáticos y delitos comunes cometidos a través de la informática, Valencia: Tirant lo Blanch, 2001. p. 127.
} 
de la Convención de Derechos del Niño, Estados Unidos de Norteamérica (en adelante, Estados Unidos) únicamente ha suscrito ambos instrumentos sin ratificarlos $\mathrm{y}$, además, ha formulado reservas, en el sentido que asumir las obligaciones del Protocolo no implicaba la ratificación de la Convención Internacional y, en lo que respecta a la pornografía infantil, no se obligaba a la asimilación del concepto propuesto $\mathrm{y}$, en consecuencia, se reservó la aplicación de uno diferente. ${ }^{2}$

Pues bien, lo anterior no quiere decir que en Estados Unidos no exista la voluntad de sancionar las conductas asociadas a la pornografía infantil, sino que, tal como explica Akdeniz, ${ }^{3}$ en el ámbito anglosajón, se entiende que la regulación internacional llega siempre tarde y que, además, es deficiente e innecesaria frente a la protección que dispensan las leyes penales nacionales. En consecuencia, no existe interés en asumir obligaciones de tipificación ni mucho menos se comparte la idea de asimilación de los conceptos afianzados en los tratados, puesto que se estima que el derecho interno satisface de modo correcto y suficiente los requerimientos de protección de la infancia. Lo anterior se diferencia de la realidad europea donde los tratados internacionales han operado como guía en la tipificación por parte de los Estados miembros. ${ }^{4}$

${ }^{2}$ El estado actual de ratificación de la Convención y el Protocolo puede consultarse en la página de la ONU, disponible en el sitio web: http://treaties.un.org/Pages/ViewDetails.aspx?src=TREATY\&mtdsg_no=IV$11 \mathrm{c} \&$ chapter $=4 \&$ lang=en [visitado el 07.04.2010]. La razón de este punto vista, está en que el asumir un concepto determinado de pornografía y, en particular, el señalado en el Protocolo, implicaría limitar la definición de la misma a un parámetro, donde lo único importante es que se muestre a los menores realizando una acción sexual, "con independencia de si es portadora o no de valores científicos, pedagógicos, artísticos, etc.". ORTS BERENGUER, Enrique; ROIG TORRES, Margarita, "Las recientes reformas a los delitos contra la libertad e indemnidad sexuales", Cuadernos de Politica Criminal, $\mathrm{n}^{\circ} 84$ (2004), p. 137. Vid. ampliamente, MORILLAS FERNÁNDEZ, David, Análisis dogmático y criminológico de los delitos de pornografía infantil: Especial consideración de las modalidades comisivas relacionadas con Internet, Madrid: Dykinson S.L., 2005, pp. 43 y ss.

3 AKDENIZ, Yaman, Internet Child Pornography and the Law: National and International Responses, Padstow, Cornwall: TJ International Ltd., 2008. p.168.

${ }^{4}$ Vid. TAMARIT SUMALLA, Josep María, La protección penal del menor frente al abuso y explotación sexual: análisis de las reformas penales de 1999 en materia de abusos sexuales, prostitución y pornografia de menores, Navarra: Aranzadi Editorial, 2000. pp. 40-53. En general la existencia de instrumentos internacionales en el ámbito europeo es mucho más amplia. Así, por ejemplo, la Resolución del Parlamento Europeo de 19 de septiembre de 1996, sobre menores víctimas de la violencia, donde se recomienda la creación de unidades policiales especializadas en la persecución de la delincuencia sexual infantil y la cooperación internacional contra el crimen organizado; Resolución de la Asamblea Parlamentaria del Consejo de Europa 1099, de 15 de septiembre de 1996, sobre explotación sexual de menores; Resolución 51/77 de 20 de febrero de 1997 de la Asamblea General de Naciones Unidas, sobre derechos del niño, en orden a prevenir el tráfico sexual internacional de menores; Resolución sobre la Comunicación de la Comisión relativa a los contenidos ilícitos y nocivos en Internet, de 24 de abril de 1997, que busca promover la formación de Policías especializadas en la persecución de la pornografía infantil; Resolución del Consejo Europeo de 6 de noviembre de 1997, también sobre explotación sexual infantil, y Protocolos facultativos de la Convención de Derechos del Niño relativos a la participación de niños en conflictos armados, venta de niños, prostitución infantil y utilización de niños en pornografía, adoptados en la Asamblea de Naciones Unidas (A/54); Propuesta de Decisión Marco del Consejo relativa a la lucha contra la explotación sexual infantil y la pornografía infantil (2001/2025 (CNS) y Anexo de la Comunicación de la Comisión al Consejo y Parlamento Europeo sobre lucha contra la trata de seres humanos, la explotación sexual y la pornografía infantil 2001/0025 (CNS), aprobada por Resolución Legislativa del Parlamento Europeo sobre cooperación policial y judicial en materia penal 06/2001 (A5-0206/2001); Moción de la Asamblea Parlamentaria del Consejo de Europa sobre la "protección de los menores contra la pornografía infantil en Internet" de 7 de mayo de 
OXMAN, Nicolás. “Aspectos político-criminales y criminológicos de la criminalización de la posesión de pornografía infantil en Estados Unidos de Norteamérica".

Se denota, entonces, el primer objetivo de este trabajo: constatar si, efectivamente, la regulación penal de Estados Unidos, en lo que se refiere a los delitos de pornografía infantil, $\mathrm{y}$, en particular, en lo que toca al delito de posesión o almacenamiento de dicho material, es entendida en dicho país como eficaz. Lo anterior, únicamente puede ser posible sobre la base de develar los principios político-criminales que han guiado al legislador, como también, las recomendaciones jurisprudenciales en este ámbito. Una vez develado dicho punto de vista, se hace necesario examinar la justificación, alcance y límites del delito de posesión de material pornográfico en Estados Unidos. Finalmente, dedicaremos un apartado especial a la indagación sobre el sustento criminológico de la argumentación dada por el legislador para amparar el castigo de la posesión de pornografía infantil.

\section{La necesaria referencia a la discusión político-criminal sobre la legitimidad del castigo de la pornografía de adultos en Estados Unidos: los parámetros dados para la "obscenidad" y "posesión privada"}

Para el análisis de la evolución político-criminal de la penalización de la pornografía infantil en Estados Unidos, resulta fundamental hacer referencia a la regulación que existía con anterioridad a la existencia de leyes penales específicas. ${ }^{5}$ Pues bien, antes que el United States Code (en adelante, Código Penal Federal), sistematizara de modo expreso la materia en su capítulo 111, denominado: "Explotación sexual y otros abusos de niños" (sexual exploitation and other abuses of children), dentro del parágrafo \$2252A, titulado: "Determinadas actividades en relación al material que constituya o contenga pornografía infantil" (certain activities relating to material constituting or containing child pornography), la pornografía, sin distinción ni categoría especial alguna, era abordada con un criterio legal unitario que, en general, se remitía a la valoración de lo que cada Tribunal entendiera por "obscenidad", cuestión que se regula, incluso hasta hoy, en el capítulo 71, parágrafos $§ 1460$ y siguientes del citado Código. ${ }^{6}$

Este tratamiento no diferenciado de la pornografía, se estructuraba como una serie de reglas abstractas, plagadas de apreciaciones de orden subjetivo que se integraban con contenidos socioculturales que, elevados a la categoría de estándar probatorio, servían para determinar cuándo un material podía ser considerado "obsceno" y, por ende, alcanzar la categoría de una cuestión merecedora de sanciones penales. Dichos criterios fueron establecidos en 1973 por la Corte Suprema, en la decisión del caso Miller $v$. California, ${ }^{7}$ para después ser

2001;Propuesta de Decisión Marco del Consejo de Europa relativa a la lucha contra la trata de seres humanos y lucha contra la explotación sexual de los niños y la pornografía infantil, de 14 de diciembre de 2001; Recomendación Número 1583 de 2002, del Consejo de Europa a los gobiernos para que coordinen esfuerzos contra la pornografía infantil y la explotación sexual de niños; Decisión Marco 2004/68/JAI del Consejo de 22 de diciembre de 2003, relativa a la lucha contra la explotación sexual de niños y a la pornografía infantil. Vid. MORILLAS, Análisis dogmático, cit. nota $\mathrm{n}^{\circ} 2$, p. 35. También, debe consultarse, especialmente, el reciente Convenio del Consejo de Europa para la protección de los niños contra la explotación y el abuso sexual, hecho en Lanzarote el 25 de octubre de 2007, publicado en el Boletín Oficial del Estado de España, n - 274, de 12 de noviembre de 2010.

${ }^{5}$ Vid. MATTEI, Monique; CASEY, Eoghan; McGRATH, Michael, Investigating child exploitation and pornography: The Internet, the Law and Forensic Science, San Diego: Elsevier Academia Press, 2005, p. 227. ${ }^{6}$ Vid. Federal Criminal Code and Rules, New York: West Group, Westlaw, 2000, p. 673.

${ }^{7}$ United State Supreme Court, Miller v. California, 413, U.S. 15 (1973), disponible en el sitio web: http://www.law.cornell.edu/supct/html/historics/USSC_CR_0413_0015_ZS.html [visitado el 21.07.2009]. 
transcritos a modo de recomendación legal para los Estados en la Sección 251.4., del Código Penal Modelo (Model Penal Code), bajo el rótulo “Obscenidad” (obscenity). ${ }^{8}$

En cuanto al contexto material en que tuvo lugar el citado caso Miller, cabe señalar que, a principios de los años setenta del siglo recién pasado, el material pornográfico que incluía actividades sexuales explícitas de dos o más personas, o bien, la exhibición manifiesta de los órganos sexuales de las personas que intervienen en dichas conductas (el llamado género hard-core o pornografía dura), se masificó comercialmente en Estados Unidos. ${ }^{9}$ Por ello, tocaría decidir -como consecuencia de la judicialización del asunto- si dicho género contravenía o no la legislación vigente, en el sentido de que podía ser considerado como algo "obsceno"; concepto al cual se circunscribían los límites a la libertad de expresión y, por tanto, la posibilidad de que los Estados incriminaran la comercialización o producción de dicho material, asunto que, sin embargo, ya contaba con un precedente jurisprudencial de la Corte Suprema, por cierto, negativo para los intereses de la industria pornográfica. ${ }^{10}$

En este contexto, el caso Miller v. California, se pronuncia sobre la legalidad de la producción, distribución y comercialización de material pornográfico con exhibición expresa de los órganos sexuales. Lo trascendente es que la Corte Suprema señala el método para decidir cuándo algo puede ser considerado "obsceno" y, por ende, si se trata de un objeto susceptible de ser prohibido y criminalizado por los Estados, en razón de no encontrar amparo en la libertad de expresión contenida en la primera enmienda de la Constitución. En virtud de lo anterior, la Corte dice que la prueba de "lo obsceno" no depende de lo que puedan considerar las autoridades de los Estados, sino de lo que entienda una persona promedio, aplicando un estándar según el cual es necesaria la acreditación en el juicio de la valoración de lo que la comunidad contemporánea considera como tal; la Corte apela a un interés lascivo, a si la obra representa o describe, en una forma ofensiva una conducta sexual explícita, y también si el trabajo o material, en su conjunto, carece de sentido literario, artístico, político o de valor científico. ${ }^{11}$

\footnotetext{
${ }^{8}$ Vid. ROBINSON, Paul, Criminal Law: Case Studies \& Controversies, New York: Wolters Kluwer, 2008. pp.1156-1157. SALTZBURG, Stephen; DIAMOND, Jhon, KINPORTS, Kit; MORAWETZ, Thomas, Criminal Law: Cases and Materials, 2a ed. New York: Lexis Nexis, 2000. pp. 973 y 974.

9 Según Guglielmi entre las décadas de los años sesenta y setenta, Estados Unidos experimentó una revolución sexual que incluía la creciente tolerancia y aceptación social de la pornografía hard-core, cuestión que las nuevas generaciones entendían como un derecho amparado en la libertad de expresión. GUGLIELMI, Kelly, "Virtual child pornography as a new category unprotected speech", CommLaw Conspectus, n ${ }^{\circ} 9$ (2007), pp. 207 y ss.

${ }^{10}$ En 1957 la Corte Suprema había declarado en el caso Roth v. United States que las manifestaciones obscenas carecen en lo absoluto de la protección constitucional que brinda la libertad de expresión. Este caso se trataba de dos individuos que fueron sentenciados por vender y distribuir por correo libros y avisos calificados como "obscenos" por las leyes de California (Roth v. United States, 354 U.S. 476, 1957). MILSTEAD, Virginia, "Ashcroft v. Free Speech Coalition: how can virtual child pornography be banned Under the first amendment?", Peppidine University Law Review, t. 35 (2003-2004), pp.829-830.

11 BARUCH, Jason, "Case comments: constitutional law: permitting virtual child pornography -a first amendment requirement, bad policy, or both? Ashcroft v. Free Speech Coalition, 535 U.S. 234 (2002)", Florida Law Review, t. 55 (2003), p.1074. BOYCE, Ronald; DRIPPS, Donald; PERKINS, Rollin, Criminal Law and Procedure, 9a ed. New York: Thomson, 2004, p. 437.
} 
OXMAN, Nicolás. “Aspectos político-criminales y criminológicos de la criminalización de la posesión de pornografía infantil en Estados Unidos de Norteamérica".

Lo apreciable de esta sentencia está en el hecho que establece como claro parámetro que no es suficiente con la apelación genérica a la "obscenidad", con ello, obliga a los Estados a ser más precisos en las definiciones legales del material que es considerado pornográfico. Por otro lado, al recurrir al "estándar de la comunidad", deja abierta la puerta a las valoraciones devenidas de la observación y acreditación de la realidad y, por ende, ajenas a las representaciones subjetivas que los miembros de la Corte puedan tener -que hasta entonces tenían, incluso, una sala especial para ver las imágenes-, ya que lo que puede ser considerado como "obsceno" en una determinada localidad, puede no serlo en otra. ${ }^{12}$ En consecuencia, si la comercialización de pornografía dura es un hecho ilícito en el plano penal, dependerá de la prueba de lo que estime cada comunidad jurídica y no de un único patrón nacional que la Corte pueda hacer aplicable y extensivo para todos los ciudadanos.

Puede decirse que, en general, este concepto jurisprudencial no se aleja de la caracterización que le ha dado la doctrina en España y en Chile a la pornografía. En efecto, se la define como "aquella representación que posee una tendencia objetivada a excitar sexualmente y carece de todo valor literario, artístico o científico", ${ }^{13}$ siendo común la apelación o referencia a la exigencia de la manifestación de una conducta sexual explícita, ${ }^{14}$ lo anterior denotaría la influencia mediata del pensamiento norteamericano en este punto como se desprende de la exigencia de idénticos requisitos copulativos por parte de un importante sector de la doctrina española ${ }^{15}$ y chilena, ${ }^{16}$ pero con la salvedad de que no se pide el estándar de prueba de la estimación de obscenidad por parte de la comunidad.

Abordados los parámetros dados por la Corte Suprema para la conceptualización de la obscenidad, cabe hacerse cargo de los criterios establecidos para determinar la posibilidad

12 "The Miller Court also opted for a "community standard" test rather than a "national standards" test. The Court reasoned that community standards are more appropriate to judge obscenity because it would be too difficult for juries to discern a national standard of acceptable content". MATTEI/CASEY/McGRATH, Investigating child exploitation, cit. nota $\mathrm{n}^{\circ} 5$, p. 229.

${ }^{13}$ DÍEZ RIPOLLÉS, José Luis, Exhibicionismo, pornografía y otras conductas sexuales provocadoras: la frontera del derecho penal sexual, Barcelona; Bosch, 1982. p. 278.

${ }^{14}$ BOLDOVA PASAMAR, Miguel Ángel, "Comentario al art.189”, en: Díez Ripollés, José Luis; Romeo Casabona, Carlos María (coords.), Comentarios al Código Penal. Parte Especial, t. II, Valencia: Tirant lo Blanch, 2004. p. 531. MUÑOZ CONDE, Francisco, Derecho Penal: Parte especial, $16^{\mathrm{a}}$ ed. Valencia: Tirant lo Blanch, 2007. p. 242.

${ }^{15}$ Así, se exigen los siguientes requisitos: “a) un material que tomado en su conjunto aparece dominado por un interés libinidoso; b) que es potencialmente ofensivo porque se desvía de los estándares contemporáneos de la comunidad relativos a la representación de material sexuales; c) que se halle falto totalmente de valor social y que tomado en su conjunto carezca de un serio valor artístico, literario, científico y político". ORTS BERENGUER, Enrique; SUÁREZ-MIRA RODRÍGUEZ, Carlos, Los delitos contra la libertad e indemnidad sexuales, Valencia: Tirant lo Blanch, 2001. p. 198. Con expresa mención al caso Miller vs. California, MORILLAS Análisis dogmático, cit. nota n 2, p. 242.

${ }^{16}$ Así, SÁNCHEZ PECAREVIC, Claudio, Delito de almacenamiento de pornografia infantil, Santiago: Ed. Librotecnia, 2010. p. 83. MOLINA CANTILLA, René, Delitos de pornografía infantil, Santiago: Ed. Librotecnia, 2008. p. 29. GARRIDO MONTT, Mario, Derecho Penal: Parte especial, t. III, $3^{\text {a }}$ ed. Santiago: Ed. Jurídica de Chile, 2007. p. 398. RODRÍGUEZ COLLAO, José Luis, Delitos sexuales, Santiago: Ed. Jurídica de Chile, 2004. p. 244. Con matices, ETCHEBERRY, Alfredo, Derecho Penal: Parte especial, t. IV, $3^{\mathrm{a}}$ ed. Santiago: Ed. Jurídica de Chile, 2004. p. 90. LABATUT GLENA, Gustavo, Derecho Penal, t. II, $7^{\mathrm{a}}$ ed. Santiago: Ed. Jurídica de Chile, 2007. pp. 150-151. Únicamente, se refieren al concepto legal restringido de pornografía infantil. POLITOFF, Sergio; MATUS, Jean Pierre; RAMÍREZ, Cecilia, Derecho Penal: Parte especial, $2^{\text {a }}$ ed. Santiago: Ed. Jurídica de Chile, 2005. p. 286. 
de criminalizar la posesión de material pornográfico cuyo contenido sexual se refiere a imágenes de adultos. Al respecto rige hasta hoy el criterio dado por la misma Corte en la decisión del caso Stanley v. Georgia ${ }^{17}$ donde se pronunció señalando que la tenencia privada de material lascivo dentro del hogar, no puede ser considerado algo lesivo, por no lesionar interés alguno, es decir, no es algo "obsceno", puesto que no afecta los sentimientos de la comunidad y, por ende, tampoco es susceptible de ser criminalizado como un delito, ya que ella -la posesión de material pornográfico dentro de la esfera privada- queda amparada por la extensión de la protección que dispensa el derecho a la libertad individual contenido en la primera enmienda de la Constitución; por consiguiente, tales comportamientos si son desarrollados en una dimensión privada quedan sujetos a los designios de la autorresponsabilidad en el ejercicio de la libertad e intimidad individuales. ${ }^{18}$ La Corte Suprema estimó que, independientemente de la valoración social que pueda recaer sobre el contenido de ese material, el derecho a recibir e intercambiar cualquier tipo de información, como también cualquier clase de ideas, es fundamental para una sociedad libre; la argumentación de la decisión sostuvo que las personas tienen derecho a permanecer ajenas a las intromisiones gubernamentales no deseadas en este ámbito de la intimidad $\mathrm{y}$, por ello, se excluye toda penalización de la mera posesión de material "obsceno" utilizado o almacenado en la privacidad del propio domicilio. ${ }^{19}$ La Corte Suprema entiende que permitir que los Estados castiguen dicha posesión implica utilizar la ley para el control de la moralidad pública, además, de instrumentalizar a las personas en el plano íntimo de sus pensamientos, cuestión que no puede lograrse dentro de los límites de la Constitución de los Estados Unidos. Lo anterior se desprende del voto del Juez Marshall:

"If the First Amendment means anything, it means that a State has no business telling a man, sitting alone in his own house, what books he may read or what films he may watch. Our whole constitutional heritage rebels at the thought of giving government the power to control men's minds". 20

Estas son prácticamente las mismas argumentaciones que se erigen en contra de la criminalización de la posesión de pornografía infantil en la doctrina española. Es así como se señala que, por un lado, el legislador al castigar este tipo de conducta invade la privacidad a niveles "difícilmente compatibles con el derecho constitucional a la

\footnotetext{
${ }^{17}$ En el Derecho Penal de Estados Unidos este caso se enseña como un clásico ejemplo de los límites al poder punitivo en relación a la protección otorgada por la primera enmienda. Vid. DUBBER, Markus; KELMAN, Mark, American criminal law: Cases, statutes, and comments, New York: Thomson West, 2005. p. 79-81.

${ }^{18}$ GUGLIELMI, "Virtual", cit. nota n ${ }^{\circ}$ 9, p. 210.

${ }^{19}$ WATANABE, Jacqueline, "Real Problems, virtual solutions: the (still) uncertain future of virtual child pornography legislation", Journal of Technology Law \& Policy, t. 10 (2005), p. 220.

20 "Si la Primera Enmienda significa algo, es que un Estado no tiene derecho a decirle a una persona qué libros puede leer o que películas ver en su hogar. Toda nuestra herencia constitucional se rebela ante la idea de otorgarle al gobierno el poder para controlar las mentes de las personas." United States Supreme Court, Stanley v. Georgia, 394 U.S. 557 (1969), disponible en el sitio web: http://www.law.cornell.edu/supct/html/historics/USSC_CR_0394_0557_ZS.html [visitado el 08.09.2009].
} 
OXMAN, Nicolás. “Aspectos político-criminales y criminológicos de la criminalización de la posesión de pornografía infantil en Estados Unidos de Norteamérica".

intimidad" 21 y, por el otro, se sostiene acertadamente que, en la realidad material, no se lesiona ningún tipo de bien jurídico de naturaleza sexual. ${ }^{22}$

Haciendo eco de tales razonamientos, habría que concluir necesariamente, sobre la base de los precedentes afianzados a partir de las decisiones de la Corte Suprema en los casos Miller v. California y Stanley v. Georgia, que de ser estos aplicados a la pornografía infantil, traerían aparejados: primero, que los tribunales, siguiendo el criterio del caso Miller, exigieran para definir la licitud o ilicitud del material, la representación visual de niños en actividades sexuales explícitas que involucren sus órganos sexuales, de modo que la sola exposición de sus cuerpos desnudos a través de fotografías o videos no cumpliría con el parámetro de "obscenidad" señalado por el máximo tribunal; segundo, que según las reglas fijadas en el caso Stanley v. Georgia la posesión y consumo privado de ese material dentro del hogar sería siempre lícito, toda vez que su castigo implicaría el uso de la ley a favor de la moral y la vulneración de las garantías constitucionales esenciales basadas en la libertad. $^{23}$

Lo cierto es que, como veremos, la pornografía infantil y, en especial, la justificación del castigo de su posesión, tuvo en Estados Unidos un derrotero totalmente diferente. Develar las razones que esgrimió el legislador para crear un tipo especial de pornografía infantil, definiéndola y castigando también su tenencia privada es el objeto de los párrafos que siguen.

En efecto, de lo que se trata es de descubrir por qué los razonamientos aplicados para justificar la pornografía de adultos fueron desestimados tratándose de menores de edad, ya que, por una parte, en la actualidad, la pornografía infantil es conceptualizada en el parágrafo §2251 (c) (1) (A), del Código Penal Federal como "cualquier representación visual que envuelve el uso de un menor participando en una conducta sexual explícita" ${ }^{24}$ y, de otra parte, la posesión de pornografía infantil es regulada, de modo específico, en el parágrafo §2252A (4) (B), que castiga "a toda persona que con conocimiento posea cualquier libro, revista, periódico, película, cinta de video, disco de computadora, o bien, cualquier otro material que contenga imágenes de pornografía infantil que haya sido enviado por correo, por encargo o transporte interestatal o comercio extranjero por cualquier medio, incluyendo por computadora, o que hayan sido producidos usando materiales enviados por correo, por encargo o transporte interestatal o comercio extranjero o por cualquier medio, serán penados según lo previsto en la subsección (B)", 25 estableciéndose, en la actualidad, un criterio limitativo de penalidad para los Estados, ya que estos no pueden asignar una pena superior a los 15 años de privación de libertad para este delito.

\footnotetext{
${ }^{21}$ Así, por ejemplo, MUÑOZ CONDE, Francisco, Derecho Penal, cit. nota ${ }^{\circ} 14$, p. 247.

22 Entre otros, CARMONA SALGADO, Concepción, "Lección 10. Delitos contra la libertad sexual (II)", Derecho Penal español: Parte especial. Cobo del Rosal, Manuel (coord.), 2a ed. Madrid: Dykinson, 2005. p. 318.

${ }^{23}$ SLOCUM, Brian, "Virtual child pornography does it mean the end the child pornography exception to the first amendment?", Albany Law Journal of Science \& Technology, Vol. 14 (2004), p. 644.

${ }^{24}$ Vid. Federal Criminal Code, cit. nota ${ }^{\circ} 6$, p. 762.

${ }^{25}$ Vid. Federal Criminal Code, cit. nota ${ }^{\circ} 6$, pp. 767 y 768.
} 
Polit. crim. Vol. 6, № 12 (Diciembre 2011), Art. 2, pp. 252 - 294.

[http://www.politicacriminal.cl/Vol_06/n_12/Vol6N12A2.pdf]

\section{Hacia la concepción de la pornografía infantil como una categoría diferenciada y merecedora de una protección legal especial}

La regulación legal específica de la pornografía infantil debe ser analizada y comprendida, como señalan Mattei, Casey y McGrath, ${ }^{26}$ como una consecuencia de la evolución tecnológica la que constituye, sin duda, una forma de expresión de la libertad en cuanto se manifiesta como una creación humana. Entonces, la preocupación legislativa no es sino efecto o reflejo de un conflicto de intereses que se resuelve sobre la base de la lógica ponderación material de costes que una sociedad democrática debe efectuar, determinado cuáles son las formas de expresión que la Constitución protege $\mathrm{y}$, dentro de estas, cuáles son las que resultan incluidas o excluidas de la dispensa que otorgan a nivel federal la primera enmienda -según la cual se prohíbe hacer leyes que impliquen una limitación o restricción a la libertad de expresión- y la decimocuarta enmienda (en sentido amplio, igualdad ante la ley). Es así que, como veremos, con posterioridad a la década de los setenta del siglo XX, se intentará encontrar un equilibrio entre, por un lado, los derechos legítimos de la libertad de expresión y, por el otro, la necesidad político-criminal del Gobierno Federal por dar respuesta al reclamo ciudadano de mayor regulación de la pornografía infantil.

En efecto, a diferencia de lo que ocurre en la actualidad donde es posible ver imágenes o representaciones gráficas de niños involucrados en actividades sexuales explícitas, simplemente descargando archivos online desde una gran variedad de páginas de Internet, en los años setenta y hasta bien entrados los ochenta, del siglo recién pasado, la pornografía infantil en Estados Unidos era una actividad propia del underground, ${ }^{27}$ accesible solo por un pequeño segmento de la sociedad norteamericana, a través de revistas o videos. ${ }^{28} \mathrm{Sin}$ embargo, se estaba al tanto de la existencia de una industria altamente organizada que obtenía ganancias multimillonarias, operando a escala nacional, a través del correo y ocupando instrumentos comerciales interestatales. ${ }^{29}$ Como apunta Adler desde fines de 1970, los abusos sexuales cometidos contra menores de edad son "descubiertos" como un maligno secreto cultural, "arrancado de su silencioso y oculto escondite", y elevado al nivel de "emergencia nacional", en cuyo centro estaría la pornografía infantil, sindicada por algunos como la causa principal que origina las agresiones sexuales en contra de los niños. $^{30}$

Estos cambios de valoración sociocultural repercuten rápidamente a nivel legislativo. Así en 1977 se dicta la primera ley que regula de modo expreso la pornografía infantil, la que se denominó: Children Protection Against Sexual Explotation Act. Este cuerpo legal modificó

\footnotetext{
${ }^{26}$ MATTEI/CASEY/McGRATH, Investigating child exploitation, cit. nota $\mathrm{n}^{\circ}$ 5, p. 228.

${ }^{27}$ HITT, Jason, "Child pornography and technology: the troubling analysis of United States v. Mohrbacher", University of California Davis Law Review, $t$. .34, no 4 (2001), p. 1136.

28 "La pedofilia ha encontrado un nuevo refugio en el anonimato del mundo online. A causa de las computadoras en línea, la pornografía infantil es, en la actualidad, mucho más accesible de lo que originalmente era en 1970. Adicionalmente, los avances en la tecnología informática han permitido la aparición de una nueva amenaza: la pornografía virtual”. WATANABE, "Real”, cit. nota n 19, p. 197.

${ }^{29}$ HITT, "Child", cit. nota ${ }^{\circ} 27$, p. 1134.

${ }^{30}$ ADLER, Amy, "The perverse law of child pornography”, Columbia Law Review, t. 101, n ${ }^{\circ} 2$ (2001), p. 211 .
} 
OXMAN, Nicolás. “Aspectos político-criminales y criminológicos de la criminalización de la posesión de pornografía infantil en Estados Unidos de Norteamérica”.

el parágrafo 2252 del Código Penal Federal, prohibiendo el trasporte malicioso, la distribución y venta interestatal de "representaciones obscenas visuales o impresas", en las que "se utilice a menores de 16 años en actos sexuales explícitos". Sin embargo, la nueva regulación abarcaba tan solo un aspecto de la comercialización, excluyendo de la criminalización, la venta y distribución que operaba dentro de cada Estado (es decir, la industria estatal o trading) ${ }^{31}$ que tenía lugar no solo mediante la venta directa en locales establecidos, sino también a través de la distribución por correo. ${ }^{32}$

\subsection{El reconocimiento por parte de la Corte Suprema del interés superior de la infancia: el caso New York v. Ferber}

A los citados problemas de aplicación de la ley de 1977 se les unía el precedente jurisprudencial del caso Miller. En efecto, como consecuencia de lo anterior, la distribución y comercialización de la pornografía infantil se masificó debido a que, por un lado, se consideraba que el delito de obscenidad contemplaba sanciones penales insignificantes y, por el otro, estaba siempre presente el exigente parámetro de prueba de la lesividad de los intereses de la comunidad de cara a la protección de la libertad de expresión, lo que en la práctica se tradujo en una persecución penal inútil.

En este contexto, en el año 1982, la Corte Suprema de los Estados Unidos decidió el caso New York v. Ferber, ${ }^{33}$ declarando, en resumen, por una parte, que la comercialización, difusión o distribución de pornografía infantil pasa a formar parte de las categorías de expresión de la libertad no protegidas por la primera enmienda de la Constitución y, por otra, que la legislatura podía regular legalmente su comercialización sin necesidad de tener

\footnotetext{
${ }^{31}$ La ley utilizaba la expresión "shipment" que es un tipo especial de encargo que es enviado de un Estado a otro, ya sea por barco, tren o avión.

32 ANDERSON, Wade, “Comments. Criminalizing virtual child pornography under the child pornography prevention act: is it really what it appears to be?", University of Richmond Law Review, t. 35 (2001-2002), p. 396. A mediados de la década de los setenta del siglo recién pasado, la industria de la pornografía infantil se había masificado hasta el punto de abarcar cerca de 260 tipos de revistas diferentes, las que incluían la representación de menores en actividades sexuales explícitas. En respuesta a este fenómeno el Gobierno Federal y los respectivos gobiernos de los Estados promulgaron diferentes estatutos destinados a prohibir la pornografía infantil, los que en muchos casos no requerían el cuestionamiento sobre si la "obscenidad" respondía o no al estándar desarrollado en el caso Miller. MARTS, Gary, "Constitutional law-first amendment and freedom of speech -"it's ok- she's a pixel not a pixie: The first amendment protects virtual child pornography. Ashcroft v. Free Speech Coalition. 532 US. 234 (2002)”, U.A.L.R. Law Review, n ${ }^{\circ} 717$ (2003), p. 739.

33 El caso se trataba del propietario de una librería que vendió a un agente encubierto de la Policía dos películas donde aparecían niños masturbándose; el delito por el cual se le juzgó fue el de promoción de conductas sexuales por parte de menores de 16 años, ilícito previsto en la ley del Estado de Nueva York ("sexual conduct" is in turn defined as actual or simulated sexual intercourse, deviate sexual intercourse, sexual bestiality, masturbation, sado-masochistic abuse, or lewd exhibition of the genitals). La Corte de Apelaciones del Estado de Nueva York revocó la sentencia apelada sobre la base de que el castigo de la conducta incriminada era un hecho no previsto en la ley de modo expreso y, por ello, se vulneraba la primera enmienda de la Constitución, además, el material no podía ser considerado obsceno bajo el estándar establecido en el caso Miller. BOYKIN, Charles, "Ashcroft v. Free Speech Coalition et. al.: Is the child pornography prevention act first amendment friendly, or a virtual disaster?", Southern University Law Review, t. 30 (2003), p. 265.
} 
que probar su contenido obsceno. ${ }^{34}$ Tal como veremos, tras la deliberación de este caso, el Congreso eliminó del Código Penal Federal, en lo que respecta a la pornografía infantil, el requisito del denominado "test de Miller" e intensificó la protección elevando la edad del sujeto pasivo de los 16 a 18 años. ${ }^{35}$

Los argumentos esgrimidos por la Corte Suprema de Estados Unidos para justificar su decisión, fueron los siguientes: primero, que el utilizar a menores como sujetos de la pornografía puede ser perjudicial tanto para su salud física como para su bienestar psicológico y, por ello, la pornografía infantil no está comprendida dentro de la protección que dispensa la primera enmienda; segundo, que la aplicación del estándar del caso Miller para configurar la "obscenidad" no es una solución satisfactoria al problema de la pornografía infantil; tercero, que las ganancias financieras originadas en la venta y publicidad de la pornografía infantil constituyen un incentivo para producir dicho material, lo que está prohibido en Estados Unidos; cuarto, que en el mejor de los casos el valor de permitirles a los menores realizar o aparecer en exposiciones lascivas es insignificante; y, quinto, que la distribución de fotografías y películas que representan actividades sexuales explícitas realizadas por menores de edad está intrínsecamente relacionado con el abuso sexual de los niños y, por tanto, existe un interés del Estado que justifica o faculta la prohibición de comercialización. ${ }^{36}$

Sin duda, los razonamientos apuntados para amparar la decisión del caso Ferber constituyen una importante referencia para quienes justifican una política-criminal orientada hacia el castigo y la prevención de la denominada "red de pornografía infantil", ya que, según esta postura su difusión favorece la producción de un material que requiere para su elaboración la explotación sexual de niños reales. ${ }^{37}$

En otro aspecto, en el referido caso Ferber aparece, por vez primera, la vinculación de la pornografía infantil con intereses o valores dignos de protección distintos de la libertad sexual individual, bien jurídico al que la Corte Suprema le asigna una categoría secundaria frente al interés gubernamental de resguardar el bienestar psíquico y psicológico de los menores, interés cuya protección se erigiría como una obligación de cara a la prevención de las agresiones sexuales cometidas en contra de menores de edad. En consecuencia, de un lado, se reconocen intereses relacionados con la tutela de la intimidad sexual del menor expuesto o representado en la producción del material, la que se vería afectada con la distribución de fotografías y representaciones fílmicas de jóvenes en actividades sexuales y, de otro lado, se afirma que frente a dichos valores el contenido de libertad de expresión individual restringido con la prohibición de la venta de material pornográfico -que contiene imágenes de menores que participan en actos sexuales de cualquier tipo-, es extremadamente modesto, toda vez que resulta poco probable que la representación visual

\footnotetext{
${ }^{34}$ ARMAGH, Daniel, "Virtual child pornography: criminal conduct or protected speech?", Cardozo Law Review, t. 23 (2001-2002), p. 1998.

${ }^{35} \mathrm{MATTEI} / \mathrm{CASEY} / \mathrm{McGRATH}$, Investigating child exploitation, cit. nota $\mathrm{n}^{\circ} 5, \mathrm{p} .235$. AKDENIZ, Internet Child Pornography, cit. nota ${ }^{\circ} 3$, pp. 94-95.

${ }^{36}$ AKDENIZ, Internet Child Pornography, cit. nota n 3, pp. 94-95.

${ }^{37}$ PEYSAKHOVICH, Sofya, "Virtual child pornography: Why American and British laws are at odds with each other", Albany Law Journal of Science \& Technology, t. 14 (2004), p. 807.
} 
OXMAN, Nicolás. “Aspectos político-criminales y criminológicos de la criminalización de la posesión de pornografía infantil en Estados Unidos de Norteamérica”.

de menores realizando actos sexuales o exhibiendo lascivamente partes de su cuerpo, constituya algo necesario para lograr la satisfacción de una actividad literaria, científica, o bien, de interés educacional. ${ }^{38}$ Entonces, lo que importa verdaderamente es el hecho de que la representación que se observa es siempre la manifestación directa y latente de un abuso sexual; es una conexión evidente con este, como también, conlleva la reproducción infinita de un daño físico y psicológico cometido de modo real en contra de los niños que participaron en la elaboración de dicho material. ${ }^{39}$

Así la utilización de la ley penal como método de contención de la producción de la pornografía es elevada a la categoría de prima ratio por la Corte Suprema de los Estados Unidos, señalado el juez White, en su carácter de ponente de la sentencia, que la criminalización es el método más rápido, práctico y eficaz para "secar el mercado" mediante la imposición de duras sanciones penales para las conductas de venta, publicidad o promoción de la pornografía infantil:

"The most expeditious if not the only practical method of law enforcement may be to dry up the market for this material by imposing severe criminal penalties on persons selling, advertising, or otherwise promoting the product". ${ }^{40}$

\subsection{La recepción por parte del legislador de la recomendación jurisprudencial}

En directa respuesta a la decisión del caso Ferber el Congreso promulgó una nueva ley en el año 1984, denominada expanded by the Child Protection Act, la cual modificó la edad del sujeto pasivo del delito de producción de material pornográfico, elevando la protección de 16 a 18 años. ${ }^{41}$ Junto con ello, la citada reforma suprimió -como ya se dijo- el requisito de necesidad de prueba de la "obscenidad", rompiendo, en consecuencia, con el tratamiento unitario de la pornografía, señalando, además, de modo expreso, que todo material que diga relación con pornografía infantil es de por sí lascivo aunque este no se refiera o implique la manifestación o representación de actos sexuales explícitos, como era exigible en el parámetro fijado como piso en la decisión del caso Miller. ${ }^{42}$

\footnotetext{
${ }^{38}$ ARMAGH, "Virtual", cit. nota n 34, p. 1999.

${ }^{39}$ WATANABE, "Real", cit. nota n 19, p. 199.

40 "La forma más directa y sino el método más directo de aplicación de la ley puede ser el secar el mercado para este material imponiendo sanciones penales severas a quienes venden, publicitan, o de cualquier forma promocionan el producto." United States Supreme Court, New York v. Ferber, 458 U.S. 747 (1982), disponible en el sitio web: http://www.law.cornell.edu/supct/html/historics/USSC CR 0458 0747 ZS.html [visitado el 15.06.2010].

41 ANDERSON, "Comments", cit. nota n 32, pp. 396-397.

${ }^{42}$ La palabra "lascivious" substituyó a la expresión "lewd", de modo que distinguir el criterio de valoración de la pornografía infantil (lascivious) del estándar con que se continuaría valorando la pornografía de adultos $($ lewd). WEGNER, Matthew, "Teaching old dogs new tricks: Why traditional free speech doctrine supports anti-child-pornography regulations in virtual reality", Minnesota Law Review, $t .85,{ }^{\circ} 6$ (2001), p. 2089. SHIRAZI, Emanuel, "How to constitutionally protect against virtual child pornography", Hastings Communication and Entertainment Law Journal, t. 35 (2003), p. 345. KENNEDY, Ryan, "Ashcroft v. Free Speech Coalition: Can we roast the pig without burning the house in regulating "virtual" child pornography?", Akron Law Review, n o 379 (2004), p. 385. SLOCUM, "Virtual”, cit. nota n²3, p. 646. HITT, “Child”, cit. nota n²7, pp. 1137-1138.
} 
La demanda por una persecución penal más represiva no se hizo esperar. Es así como en el año 1986 se publica una normativa complementaria de la anterior, denominada The Child Abuse and Pornography Act, dicho cuerpo legal elevó el marco punitivo mínimo recomendado a los Estados para los delitos asociados a la producción y distribución de pornografía infantil de dos a cinco años. ${ }^{43}$ Junto al incremento de las penas se criminalizó la publicidad, el marketing y la difusión de pornografía infantil. Pese a que el cambio normativo fue estimado como positivo, según afirma Shirazi, el rendimiento práctico de eficacia persecutora fue mínimo, ya que al cabo de unos pocos años las normas devinieron en obsolescencia a raíz del incremento sostenido de la comercialización de computadoras personales, las que, al posibilitar el almacenamiento de videos y fotografías como también el transporte e intercambio de información en formatos electrónicos, desplazaron casi totalmente al mercado que se dedicaba a la difusión mediante revistas y videos caseteras. ${ }^{44}$

En efecto, los cambios sociales originados en el advenimiento de los sistemas de intercambio digital a través de la creación de respaldos de archivos de información computacional, provocaron que a fines de los años ochenta (antes del nacimiento de Internet), se plantearan nuevas interrogantes, esencialmente vinculadas con la legitimidad de la posesión privada de pornografía infantil en formato computacional. En este orden de consideraciones, a mediados de 1988 se dicta otra ley, llamada The Child Protection Obscenity and Enforcement Act, la que de modo consecuencial al reconocimiento de la realidad material, viene a regular la relación existente entre las computadoras personales y la pornografía infantil, ya que el poder de difusión de información asociado al intercambio de material informático pasó a constituir el principal medio de propagación de la pornografía. ${ }^{45}$ La nueva normativa agrega en el parágrafo 2252 (a) (1) del Código Penal Federal, la prohibición expresa de cualquier intercambio (transporte, distribución o recepción), de pornografía infantil, incluyendo, expresamente el material computacional. ${ }^{46}$

\subsection{La posesión de pornografía infantil como un delito específico}

2.3.1. La diferenciación respecto de la posesión de pornografía de adultos: el caso Osborne v. Ohio

El enfoque asociado al interés superior de la infancia en oposición a valores de naturaleza individual, señalado en el caso Ferber, se amplió por la Corte Suprema al aplicar idéntica argumentación con motivo de la fundamentación de la decisión del juicio Osborne v. Ohio en el año $1990 .^{47}$ En esta sentencia se estatuye, nuevamente a nivel jurisprudencial, la imposibilidad de tutela de la libertad de expresión individual, pero ahora en referencia a la posesión de pornografía infantil, cuestión que, por cierto, iba en contra del precedente

\footnotetext{
${ }^{43}$ SEMAN, Dean, “United States v. Corp: Where to draw the interstate line on Congress' commerce clause authority to regulate intrastate possession of child pornography", Villanova S. \& Ent. Law Journal, t. 9 (2002), p. 185.

${ }^{44}$ SHIRAZI, "How”, cit. nota n' 42, p. 347.

${ }^{45}$ ANDERSON, "Comments", cit. nota $\mathrm{n}^{\circ} 32$, p. 397.

${ }^{46}$ SEMAN, "United States", cit. nota $\mathrm{n}^{\circ} 43$, p. 186.

${ }^{47}$ Este caso se trataba de un sujeto que había sido descubierto con cuatro imágenes fotográficas de menores desnudos dentro de su propio hogar. MILSTEAD, "Ashcroft", cit. nota $n^{\circ} 10$, p. 832. ANDERSON, "Comments", cit. nota n 32, p. 400.
} 
OXMAN, Nicolás. “Aspectos político-criminales y criminológicos de la criminalización de la posesión de pornografía infantil en Estados Unidos de Norteamérica”.

afianzado en la decisión del Stanley v. Georgia -que, como se dijo, sostuvo que ningún Estado podía prohibir la posesión de material obsceno en la intimidad del propio hogar-, sin embargo, en este fallo se dice que el Estado de Georgia no ha legalizado algo cuya finalidad sea el regular "la mente de los hombres", ${ }^{48}$ sino que, ha tenido como leitmotiv, en consonancia con Ferber, la protección de la infancia frente a la explotación y al daño que provocan a esta quienes elaboran material pornográfico utilizando como objetos a menores de edad; $y$, en consecuencia, resulta ser acertada la persecución penal de tal conducta, ya que, con ello, se facilita la eliminación de la oferta asociada a la producción y distribución, toda vez que la sola incriminación de tales hechos, sin referencia al destinatario del material, hace de la ley penal un instrumento inútil para la prevención del abuso sexual infantil. En efecto, el fallo señala que acá no se trata de estatuir el castigo de un hecho perteneciente a la esfera de lo privado, sino de tipificar un delito de peligro que, sobre la base de la reproducción infinita de un abuso sexual, puede conllevar -según la evidencia científica que el Tribunal tuvo a la vista-, que los menores que observan tales imágenes sean compelidos o acosados por adultos, quienes mediante la exhibición de tales representaciones sexuales, buscan seducir a los menores (grooming) ${ }^{49}$ a fin de que realicen conductas de provocación sexual bajo la argumentación engañosa de que tales prácticas pueden resultar "adecuadas" o "novedosas" para el descubrimiento de la sexualidad. Finalmente, se señala que el castigo penal de la posesión de pornografía infantil puede servir como motivación disuasiva para que los pedófilos destruyan el material. La opinión del juez White, fue la siguiente:

"The pornography's continued existence causes the child victims continuing harm by haunting the children in years to come. The State's ban on possession and viewing encourages the possessors of these materials to destroy them. Second, encouraging the destruction of these materials is also desirable because evidence suggests that pedophiles use child pornography to seduce other children into sexual activity". 50

Entendemos que en este punto se manifiestan algunos relajos en las garantías individuales desde el momento en que, por una parte, se prefiere el castigo fácil a la cara visible de la criminalidad toda vez que resulta más pesada la prueba de la incriminación destinada al tráfico $\mathrm{y}$, por otra parte, se comete directamente una invasión en la privacidad de tal

\footnotetext{
${ }^{48}$ El Estado de Ohio esgrimió como argumentos para justificar la prohibición de la posesión de pornografía infantil, los siguientes: a) que existe un deseo estatal de destruir el material que sustenta la existencia de este mercado, concluyendo que, al decrecer la demanda la producción sería consecuentemente inferior; y, b) que las victimas de pornografía infantil sufren la existencia de un daño que se mantiene indefinidamente, mientras circule el material. ANGLIN, Howard, "The potential liability of federal law-enforcement agents engaged in undercover: Child pornography investigations". New York University Law Review, t. 77 (2002), p. 1113.

${ }^{49}$ En efecto, el Estado de Ohio apunta a la idea político criminal de forzar la destrucción de la pornografía infantil para así limitar al máximo todo posible aumento del material disponible para los pedófilos, quienes lo utilizan en la seducción de otros niños. ANDERSON, "Comments", cit. nota n 32, pp. 400 y ss.

50 "La existencia continua de la pornografía le causa a las víctimas infantiles un daño continuado al perseguirlos durante los años venideros. La prohibición de un Estado a la posesión y vista incentiva a quienes poseen estos materiales a destruirlos. En segundo lugar, el incentivar la destrucción de estos materiales es también deseable porque la evidencia sugiere que los pedófilos usan la pornografía infantil para seducir a otros niños a que tengan actividades sexuales". United States Supreme Court, Osborne v. Ohio, 495 U.S. 103 (1990), disponible en el sitio web: http://www.law.cornell.edu/supct/html/historics/USSC_CR_0495_0103 ZS.html [visitado el 05.01.2010].
} 


\section{Polit. crim. Vol. 6, No 12 (Diciembre 2011), Art. 2, pp. 252 - 294. [http://www.politicacriminal.cl/Vol_06/n_12/Vol6N12A2.pdf]}

magnitud que se lesiona sin más el derecho a la intimidad de quien posee. En efecto, por muy inmoral que parezca esta conducta no hay afectación directa de ningún bien jurídico. ${ }^{51}$

2.3.2. Legitimación doctrinal de los delitos de posesión: la tesis de la criminalidad objetiva de Fletcher

Antes de entrar en el análisis de los argumentos dados por el legislador para justificar el castigo de la posesión de material pornográfico infantil, se hace necesario indagar en las posturas doctrinales que intentan explicar en qué casos es posible recurrir a la criminalización de la posesión en Estados Unidos. Pues bien, a propósito del estudio de la tentativa, Fletcher ${ }^{52}$ señala que uno de los aspectos preocupantes es la determinación del límite preciso de dicha institución con los actos preparatorios, particularmente, en los casos en que el legislador ha decidido responder directamente mediante la tipificación de un tipo específico de comportamiento consistente en un "delito de posesión" (possession offenses), el cual debería entenderse como consumado desde el momento en que existe "conocimiento de la prohibición de la posesión". ${ }^{33}$ Como ejemplos de esta técnica legal el referido autor cita la tenencia de armas prohibidas, el material pornográfico y los estupefacientes. El problema de estos delitos está en que es posible condenar sin la prueba de que el acusado pretendía hacer algún daño a terceros con los objetos que se poseían. En efecto, se afirma ${ }^{54}$ que la posesión puede estar motivada por una finalidad enteramente inocente e incluso amparada en un motivo socialmente aceptable.

Con todo, existe una tendencia a criticar el abuso de este recurso legal de control social, indicándose, por ejemplo, que en el Estado de Nueva York es posible constatar más de 150 delitos de posesión, los que incluyen, entre otras figuras, la prohibición del porte oculto de pistolas de juguete, materiales destinados al grafiti, máquinas para estampar tarjetas de crédito, dispositivos de espionaje, etc. ${ }^{55}$ En esta línea Husak ${ }^{56}$ señala que uno de los aspectos más significativos del fenómeno está en que el legislador suele extender la ficción de la posesión hasta límites intolerables, constatándose, primero, el uso de la presunción de conocimiento de la posesión de drogas o armas de fuego, no solo para quien las porte, sino que, también a todos quienes se encuentran con este, tal como ocurre, con el castigo a título de posesión de armas a todos los ocupantes que se hallan dentro de un automóvil, tengan o no conocimiento, estén o no relacionados con quien lleva consigo las armas o la droga; segundo, el hecho que el delito de posesión desencadena la presunción de otros ilícitos, no solo del pasado, sino que, también del futuro, como la fabricación, importación o

\footnotetext{
${ }^{51}$ Vid., TAMARIT, La Protección Penal, cit. nota ${ }^{\circ} 4$, pp. 129 y ss.

${ }^{52}$ FLETCHER, George, Rethinking Criminal Law, 2a ed. New York: Oxford University Press, 2000, p. 198.

${ }^{53}$ En Inglaterra, se menciona como ejemplo, a propósito de la posesión de drogas, el caso de quien porta en su bolso sustancias introducidas por un tercero sin su conocimiento. Al respecto, existe (Misuse of Drugs Act 1971) la posibilidad de que el acusado se defienda probando que no sospechaba, ni había razón para que pudiera tener consciencia -lo que excluye el mes rea-que la sustancia que portaba era una droga controlada. MOLAN, Mike/LANSER, Denis; BLOY, Duncan, Principles of Criminal Law, 4 ${ }^{\mathrm{a}}$ ed. London: Cavendish Publishing Limited, 2000, p. 103.

${ }^{54}$ FLETCHER, Rethinking, cit. nota $\mathrm{n}^{\circ}$ 52, p. 198.

55 HUSAK, Douglas, Overcriminalization: The limits of the criminal law, New York: Oxford University Press, 2008, p. 44.

${ }^{56}$ HUSAK, Overcriminalization, cit. nota ${ }^{\circ} 55$, p. 44.
} 
OXMAN, Nicolás. “Aspectos político-criminales y criminológicos de la criminalización de la posesión de pornografía infantil en Estados Unidos de Norteamérica".

distribución, es decir, que la tenencia material sirve para deducir -a modo de inversión del peso de la prueba-, cuál es el origen y el destino; y, tercero, lo que a juicio de Husak ${ }^{57}$ resulta más sorprendente es que algunos Estados prohíban lo que se conoce como "posesión interna", que consiste en considerar como un delito de posesión de sustancias prohibidas que ya se han consumido y que se encuentran en el interior del cuerpo u organismo del acusado.

La alegación por parte de quien se defiende, en orden a que el uso tiene un propósito inocente, resulta ser un problema frente a la asentada técnica legal de castigar la posesión de objetos que objetivamente puedan también ser utilizados para fines no perjudiciales. ${ }^{58}$ Pero, además, se destaca la vaguedad de los términos dados por el legislador, donde el lenguaje se caracteriza por la existencia de tipos penales con cláusulas genéricas como, por ejemplo, en el caso de la posesión de herramientas: "cualquier otro instrumento destinado al allanamiento de morada". Ahora bien, incluso suponiendo que dichos instrumentos puedan definirse de modo preciso, los tribunales privilegian en su decisión el argumento de la existencia de una prohibición general de posesión. ${ }^{59}$ Sin perjuicio de lo anterior, se entiende que existen sentencias que niegan la constitucionalidad de la prohibición de posesión de herramientas que puedan ser empleadas en la comisión de algún delito, como tuvo lugar en el Estado de California, donde se declaró que dicha cláusula genérica adolecía del defecto de establecer una presunción de culpabilidad. ${ }^{60}$

El problema de la infracción al principio de culpabilidad debe ser solucionado involucrando dos niveles de análisis, por un lado, que la posesión de objetos no puede ser delito a menos que el legislador haya incluido como elemento de la descripción legal el hecho que la posesión de los objetos lo sea para la utilización en fines delictivos $\mathrm{y}$, por otro lado, que la carga de la prueba sobre la intención no puede ser modificada mediante el uso de una presunción legislativa. ${ }^{61}$

\footnotetext{
${ }^{57}$ HUSAK, Overcriminalization, cit. nota $\mathrm{n}^{\circ} 55$, p. 44.

${ }^{58}$ FLETCHER, Rethinking, cit. nota ${ }^{\circ}$ 52, p. 200. En efecto, se afirma que aquí tiene lugar una anticipación de punibilidad en dos niveles, por un lado, en el hecho de que se sancione la mera utilización de objetos sin tener en cuenta el resultado y, por el otro, desde el momento en que se "somete a una pena la mera posesión". SCHOEDER, Freidich-Christian. "La posesión como hecho punible" (título original: "Besitz als Straftat"), trad. Polaino-Orts, Miguel, Revista de Derecho Penal y Criminología, Universidad Nacional de Educación a Distancia, $\mathrm{n}^{\circ} 14$ (2004), p. 158.

${ }^{59}$ La legitimidad de la criminalización estaría en el citado "deber general de abstenerse de entrar en posesión", sobre la del "conocimiento" (knowingly) de la prohibición del uso o tenencia de determinados objetos. Lo cierto es que, en nuestra tradición del civil law, difícilmente puede interpretarse el delito de posesión en base a un "hacer activo" y, en consecuencia, al no haber acción base no podría entenderse la existencia de un delito de comisión por omisión, salvo que se entienda (como lo hace Pastor Muñoz) que la comisión por omisión es un título independiente de responsabilidad frente a la comisión activa y que la posición de garante es "la única cuestión esencial para afirmar o negar la responsabilidad penal". PASTOR MUÑOZ, Nuria, Los delitos de posesión y los delitos de estatus: una aproximación politico-criminal y dogmática, Barcelona: Atelier, 2005. p. 40. Señala que en realidad ni la acción ni la omisión son suficientes para justificar la existencia de los delitos de posesión, porque es en realidad un estado que, para no lesionar el principio de culpabilidad, requiere que esa posesión se realice con dolo o imprudencia. SCHOEDER, " $L a$ posesión”, cit. nota $\mathrm{n}^{\circ} 58, \mathrm{p} .167$.

${ }^{60}$ FLETCHER, Rethinking, cit. nota ${ }^{\circ} 52$, p. 199-200.

${ }^{61}$ FLETCHER, Rethinking, cit. nota $\mathrm{n}^{\circ}$ 52, pp. 200- 201.
} 


\section{Polit. crim. Vol. 6, No 12 (Diciembre 2011), Art. 2, pp. 252 - 294. [http://www.politicacriminal.cl/Vol_06/n_12/Vol6N12A2.pdf]}

Ahora bien, existe para Fletcher ${ }^{62}$ una diferencia de tratamiento entre el delito de posesión de herramientas destinadas a cometer los delitos de robo o hurto frente a las exigencias o cuestionamientos que se presentan a la hora de decidir los casos asociados o vinculados a la posesión de armas, material pornográfico y estupefacientes. Así expone que existen al menos dos razones que justifican la diferencia de tratamiento, sobre la base de la distinción entre criminalidad manifiesta (manifest criminality) en contraste con la criminalidad subjetiva (subjective criminality). ${ }^{63}$ En tal sentido, habría que distinguir, entre los delitos de posesión en donde el solo hecho de detentar la tenencia material de un objeto puede dar lugar a graves consecuencias materiales (que denomina implicancias o consecuencias siniestras (sinister implications), por el riesgo o peligro que representa ese hecho per se, como se desprende de modo concreto de artículos como armas, drogas o material pornográfico, en el que la experiencia enseña que generalmente son mantenidos con fines ilícitos. Tal criminalización resultaría plenamente aceptable, incluso, en la ausencia de prueba de un intento ulterior de realización de un delito. ${ }^{64}$ Esa exigencia no se cumpliría en el caso de la tenencia o porte de herramientas para la realización de los delitos de robo o hurto, donde no solo es dable excluir la posibilidad de recurrir a la presunción, sino que, también es exigible la acreditación del conocimiento de la prohibición del porte y la inexistencia de un fin diverso, ello porque, precisamente, la posesión de tales objetos no entraña inequívocamente un riesgo, porque no es dable pensar que se trata de elementos peligrosos para todos quienes entren en contacto con ellos. ${ }^{65}$

Se dice que el riesgo vinculado al hecho que las herramientas puedan caer en manos equivocadas no es comparable con el riesgo asociado a la descarga de un arma o del que se desprende de la circunstancia que los narcóticos puedan ser utilizados como instrumentos de propagación de la adicción o seducción de adolescentes, como tampoco, del peligro latente que se desprende de la posesión de material pornográfico, que puede afectar a terceros que entren en contacto con dicho material. ${ }^{66}$

Sobre la base de lo anterior, se entiende que esta categoría de delitos de posesión se encuentra, con las limitaciones apuntadas, plenamente justificada "debido a que el acto de posesión se manifiesta como un peligro para la comunidad, incluso si el poseedor no tiene

\footnotetext{
${ }^{62}$ FLETCHER, Rethinking, cit. nota ${ }^{\circ}$ 52, pp. 200-201.

${ }^{63}$ FLETCHER, Rethinking, cit. nota $\mathrm{n}^{\circ}$ 52, p. 200.

${ }^{64}$ Ahora bien, lo cierto es que este punto de vista que no diferencia entre los diversos tipos de delitos de posesión puede ser complementado con una clasificación que, sobre la base de la esencia del fundamento de la prohibición, señala que es posible distinguir las siguientes estructuras: a) la posesión de objetos peligrosos que es en sí peligrosa (posesión de un arma que se deja al alcance de un niño); b) posesión de objetos que pueden ser empleados de manera peligrosa (armas o perros peligrosos sin licencia); c) la posesión de objetos con la intención de cometer un delito (posesión de grandes cantidades de drogas); d) posesión de objetos que solamente son idóneos para la comisión de un delito (máquinas para falsificar moneda); e) la posesión de elementos provenientes de un delito (pornografía infantil). PASTOR, Los delitos de posesión, cit. nota $\mathrm{n}^{\circ} 59$, pp. 48-55.

${ }^{65}$ FLETCHER, Rethinking, cit. nota $\mathrm{n}^{\circ} 52$, p. 200.

${ }^{66}$ FLETCHER, Rethinking, cit. nota $\mathrm{n}^{\circ} 52$, p. 201. Este modo de justificar la punibilidad es comparable con aquella tesis que señala, con matices en cuanto a su naturaleza y número, que existen delitos de posesión "con intención de utilización", que serían delitos de tendencia interna trascendente y de peligro abstracto, con independencia de que su fundamento se encuentre en una presunción de un peligro. SCHOEDER, "La posesión”, cit. nota $n^{\circ} 58$, p. 160. PASTOR, Los delitos de posesión, cit. nota $n^{\circ}$ 59, p. 60 .
} 
OXMAN, Nicolás. “Aspectos político-criminales y criminológicos de la criminalización de la posesión de pornografía infantil en Estados Unidos de Norteamérica”.

fines delictivos". La inferencia de la presunción se justifica sobre la base de la existencia de otro factor derivado del "riesgo que representa que tales objetos caigan en manos equivocadas". 67

Esta forma de abordar el problema es denominada por Fletcher ${ }^{68}$ como teoría del riesgo general para la comunidad, señalando, además, que los delitos de posesión son formas de control discrecional de la sociedad. Al contrario, nosotros estimamos que la criminalización de la posesión de la pornografía infantil requiere, al menos, de la comprobación científica de la existencia de dicho peligro de que "los objetos caigan en manos equivocadas", o bien, que puedan usarse sin "propósitos inocentes", ya que, de otro modo, existiría un uso irracional del Derecho Penal como medio de control formalizado. Al no existir un parámetro claro que permita medir ese riesgo -como se verá infra en relación al aspecto criminológico-, el castigo de este delito de posesión supone una intromisión intolerable en la esfera individual; un despropósito, que además de no servir para la protección de ningún bien jurídico termina por confiscar el ejercicio de la libertad individual; es tan desacertado como la punición de la posesión de droga para el consumo, o la fabricación de armas, para evitar los eventuales riesgos futuros de lesión de bienes indeterminados, todo lo cual constituye una intromisión intolerable en la esfera privada y una vulneración clara del principio de prohibición de exceso.

Es más, desde el punto de vista de la estructura conceptual de este tipo de infracciones la punición del consumo privado de pornografía infantil supone la prueba de la afirmación de que el contacto con ese tipo de material crea un peligro de realización efectiva de acciones de abuso sexual en contra de menores. En tal sentido, no es ni un delito de peligro concreto ni abstracto, toda vez que, como veremos, no se ha podido probar la efectividad de la existencia de un riesgo para bien jurídico alguno -al menos en términos probabilísticos-; en consecuencia, no es sino un delito de posesión por cierto, pero instituido sobre la base de la mera posibilidad de crear un peligro no probado. ${ }^{69}$ En efecto, tal como afirman Dubber y Kelman $^{70}$ ese poder policial relativo al control de la posesión de determinados bienes cuya tenencia se estima peligrosa, no puede implicar una limitación a los derechos constitucionales; la prohibición de posesión de ciertos objetos no puede ser vista como una cuestión irracional, arbitraria o caprichosa. En tal sentido, dichos autores hacen referencia a dos casos en los cuales se declaró inconstitucional el delito de posesión de maquinaria destinada a la fabricación de tarjetas de crédito, como también, un caso en el cual se estimó como arbitraria la criminalización del porte de artículos de pesca (State v. Saiez y Delmónico v. State, respectivamente).

\footnotetext{
${ }^{67}$ Este argumento es similar a lo señalado por Pastor Muñoz quien afirma que "aunque estos tipos renuncian a que el comportamiento del auto sea objetivamente peligroso para bienes jurídicos individuales, respetan la exigencia de que el comportamiento tipificado constituya una perturbación social”. PASTOR, Los delitos de posesión, cit. nota $\mathrm{n}^{\circ} 59, \mathrm{p} .63$.

${ }^{68}$ FLETCHER, Rethinking, cit. nota $\mathrm{n}^{\circ}$ 52, p. 201.

${ }^{69}$ DÍEZ RIPOLLÉS, Exhibicionismo, Pornografía, cit. nota n ${ }^{\circ}$ 13, pp. 147 y ss. MÉNDEZ RODRÍGUEZ, Cristina, Los Delitos de Peligro y sus Técnicas de Tipificación, Madrid: Universidad Complutense de Madrid, 1993, pp. 137 y ss.

${ }^{70}$ DUBBER/ KELMAN, American criminal law, cit. nota n ${ }^{\circ}$ 17, pp. 81-82.
} 


\section{Polit. crim. Vol. 6, No 12 (Diciembre 2011), Art. 2, pp. 252 - 294. [http://www.politicacriminal.cl/Vol_06/n_12/Vol6N12A2.pdf]}

Una posición crítica afirma que la técnica legal de prohibir la posesión per se puede estar inspirada en la consideración de una "clase especial de personas" que es estimada como peligrosa. ${ }^{71}$ Lo anterior se denota, por ejemplo, en el hecho de que el Código Penal de California prohíba la posesión de armas por personas que han sido condenadas por el delito de hurto agravado, receptación o delitos similares contra la propiedad, pero no por ciudadanos que nunca han sido sancionados penalmente. Si este tipo de normativa se justifica, lo sería por el argumento de que la posesión de ciertos artículos por criminales condenados es más peligrosa que si el mismo acto de posesión es detentado por personas sin antecedentes penales. ${ }^{72}$

La promulgación de prohibiciones en contra de criminales con antecedentes penales es la culminación de la filosofía de la criminalidad subjetiva, cuyo propósito es perseguir crímenes o delitos que pueden servir para identificar o aislar a "personas peligrosas". ${ }^{73}$ Fletcher entiende que este estilo de razonamiento es una invitación al Derecho Penal de clase que, incluso, podría apoyar la introducción de criterios racistas a la definición de los delitos, apoyándose en estadísticas que demuestren la tendencia de una determinada raza a cometer más crímenes que otra. ${ }^{74}$

El mismo autor explica que resulta criticable que los delitos de posesión sean utilizados como formas de control de grupos determinados de la sociedad, como ocurre, por ejemplo, con la prohibición de uso de armas que establece la legislación del Estado de California para los extranjeros, ya que, evidentemente, no todos los extranjeros son peligrosos. ${ }^{75}$ En tal sentido, continúa afirmando que esta mentalidad tiene su origen en una traslación de los criterios actuariales de medición del riesgo que realizan las compañías de seguros, los que serían presumiblemente adecuados para la definición legislativa de delitos. ${ }^{76}$ Por ello, la exigencia de que la posesión involucre la prueba de la intención de hacer daño contrarresta la mentalidad actuarial y reconstituye el delito como un acto criminal voluntario y dirigido, en el caso particular, a la comisión de un daño. ${ }^{77}$

\footnotetext{
${ }^{71}$ FLETCHER, Rethinking, cit. nota $\mathrm{n}^{\circ}$ 52, p. 202.

72 Se dice que este tipo de legislación tiene por antecedente en el derecho comparado a la filosofía nacionalsocialista; el hecho es que la disposición alemana se introdujo en 1933 como parte de una campaña nazi para combatir la delincuencia mediante la adopción de medidas especiales contra la "clase criminal". FLETCHER, Rethinking, cit. nota $\mathrm{n}^{\circ}$ 52, p. 202. Ahora bien, con algunas modificaciones el Código Penal alemán (en adelante, $S t G B$ ) "contiene el mandato de no poseer determinados objetos que puedan brindar al condenado la oportunidad o el incentivo de cometer hechos punibles (\&\& 56c párrafo 3; 68b párrafo 1 núm. 5 $S t G B$ '. En realidad, el antecedente es incluso más remoto, ya que pueden encontrarse delitos de posesión en la Ley alemana contra el uso criminal y el peligro público de explosivos de 1884. SCHOEDER, "La posesión”, cit. nota $\mathrm{n}^{\circ} 58, \mathrm{p} .155$.

${ }^{73}$ FLETCHER, Rethinking, cit. nota $\mathrm{n}^{\circ}$ 52, pp. 197- 205.

${ }^{74}$ FLETCHER, Rethinking, cit. nota $\mathrm{n}^{\circ}$ 52, p. 203.

${ }^{75}$ FLETCHER, Rethinking, cit. nota $\mathrm{n}^{\circ}$ 52, p. 203.

${ }^{76}$ Tal como las compañías de seguros pueden negar la cobertura a determinados grupos de edad, con elevados índices de accidentes de tránsito, el Estado puede negar el derecho a poseer armas de fuego a una determinada clase de personas que muestran tendencias peligrosas. FLETCHER, Rethinking, cit. nota $\mathrm{n}^{\circ}$ 52, p. 204.

${ }^{77}$ FLETCHER, Rethinking, cit. nota ${ }^{\circ}$ 52, p. 204.
} 
OXMAN, Nicolás. “Aspectos político-criminales y criminológicos de la criminalización de la posesión de pornografía infantil en Estados Unidos de Norteamérica".

2.3.3. La justificación legislativa de la incriminación de la posesión de pornografía (el peligro abstracto de utilización del material en la futura comisión de un delito sexual), en contraposición a la posición jurisprudencial de la necesidad de prueba de un daño real y efectivo

Según habíamos señalado, pese a considerar un defecto en la descripción de la conducta, la Corte Suprema en el caso Osborne legitimó constitucionalmente la penalización de la posesión de la pornografía infantil a nivel estatal, considerando para ello, como principal argumento, el hecho de que tal material representa, en esencia, la utilización de seres humanos como objetos sexuales, constituyendo tal delito un método eficaz para frenar el mercado de difusión y producción, evitando la realización de otros abusos sexuales contra menores; la consideración del peligro asociado a la utilización en la comisión de un delito sexual de contacto fue, según se puede desprender de lo expuesto anteriormente, una cuestión tangencial que sirvió únicamente de apoyo al desarrollo de la tesis principal.

Ahora bien, recogiendo tal recomendación político-criminal el Congreso de los Estados Unidos sancionó una nueva la ley (The Child Protection Restoration and Penalties Enhancement Act of 1990), que introduce derechamente el castigo expreso a todo quien bajo su conocimiento ("knowingly") posea imágenes, en donde se involucre a un menor en actividades sexuales explícitas. ${ }^{78}$ Se criminaliza, entonces, por primera vez la posesión de material pornográfico infantil.

Poniendo en relieve el argumento principal que se esgrimió a nivel legislativo a favor de la tipificación y relacionándolo con la tesis jurisprudencial antes expuesta, es que se puede determinar si las posiciones y criterios de necesidad coinciden. Naturalmente, no basta con sostener a nivel legal que la mera posesión de imágenes de pornografía infantil es, por sí sola, algo sobre lo cual cualquier persona puede persuadirse sobre lo perjudicial que resulta tal hecho confrontado a la necesidad de protección de la infancia. Ello, porque el recurso a la pena para proteger intereses sociales es considerado siempre algo extraordinario. ${ }^{79}$

Pues bien, una de las opiniones que se tuvo en mira durante la tramitación de la ley fue que la posesión de pornografía infantil facilita la reproducción permanente e infinita de una situación concreta de abuso o agresión sexual, toda vez que lo que se observa en las imágenes no es otra cosa que la vulneración de los derechos de un niño y, por ende, el poseedor participa o contribuye con ese hecho al tomar parte de la cadena de mercado, ya que la demanda por más material incentiva a los productores a cometer abusos. ${ }^{80}$ Hasta ahí,

\footnotetext{
${ }^{78}$ Vid. MOTA, Sue Ann, "The U.S. Supreme Court addresses the child pornography prevention act and child online protection act in Ashcroft v. Free Speech Coalition and Ashcroft v. American Civil Liberties Union", Federal Communications Law Journal, t. 55, $\mathrm{n}^{\mathrm{o}} 1$ (2002), p. 87. La referencia a la "actividad sexual explícita", se explica porque la Corte en el caso Osborne anuló el juicio, por estimar que no estaba probada o acreditada la existencia de la imputación de un delito, toda vez que las leyes del Estado de Ohio no son aplicables al mero desnudo. En efecto, las representaciones gráficas requieren "una exhibición lasciva o envolver una aproximación gráfica directa sobre los genitales". ANDERSON, "Comments", cit. nota n³2, p. 401 y ss.

${ }^{79}$ SLOCUM, "Virtual", cit. nota n²3, p. 647.

${ }^{80}$ SCHMIDT-SANDWICK, Robin, "Constitutional law-freedom of speech: Supreme Court strikes down two provisions of the child pornography prevention act (CPPA), leaving virtual child pornography virtually
} 


\section{Polit. crim. Vol. 6, № 12 (Diciembre 2011), Art. 2, pp. 252 - 294. [http://www.politicacriminal.cl/Vol_06/n_12/Vol6N12A2.pdf]}

las posturas coinciden. Pese a ello, no parece que esta tesis haya sido decisiva en la legitimación legal del castigo, pues perdía peso frente a la denominada pornografía infantil "virtual o simulada". En efecto, como se desprende en las decisiones de los casos Osborne y Ferber, la Corte Suprema habla en todo momento de "menores reales que son objeto de explotación", entendiendo por tales, los sujetos o víctimas actuales de la producción de material pornográfico. ${ }^{81}$

Paradójicamente, la razón principal por la que se entendió justificada la intervención penal en este ámbito se basó, por un lado, en la constatación de un sentir generalizado en la sociedad que, según estudios de opinión, ${ }^{82}$ revelaba un preponderantemente rechazo mayoritario hacia la posesión de pornografía infantil y, por otro lado, se dijo que en este delito existe un elevado riesgo que la sociedad no está dispuesta a tolerar, el cual consiste en la posible directa vinculación entre los adultos que consumen este tipo de pornografía y los abusos sexuales posteriores que se comenten en contra de otros menores. Se señaló que es posible hallar adultos que utilizan la pornografía infantil para seducir a los menores de edad, ${ }^{83}$ generalmente bajo engaño o prevalimiento, como también para involucrarlos en actividades sexuales, ${ }^{84}$ de modo que, sin acceso a pornografía infantil la coacción de menores para la realización de actividades sexuales se hace más difícil. ${ }^{85}$

Ahora bien, la afirmación anterior, únicamente resultaría ser efectiva, en la comprobación criminológica del peligro que subyace a la posesión de pornografía, a fin de entender por acreditada la amenaza para la salud física, mental, la seguridad y el bienestar de los niños, cuestión que podría resultar a partir de la contribución al ciclo de la pornografía infantil desde el momento en que el poseedor se convierte en productor, o bien, sobre la base de que la posesión del material incide en la comisión de un delito sexual. ${ }^{86}$ Como puede verse, en realidad, lo que es un síntoma de posible peligrosidad, ${ }^{87}$ se elevó legislativamente a la categoría de fundamento principal del castigo.

Nos parece que el Derecho Penal no es útil para detener el problema social que supone la posesión de pornografía infantil, con el castigo de un hecho como este, no se pone un freno

unregulated. Ashcroft v. Free Speech Coalition, 122 S. Ct. 1389 (2002)", North Dakota Law Review, t. 79 (2003), p. 186.

${ }^{81}$ MILSTEAD, “Ashcroft”, cit. nota n 10, p. 845. ANDERSON, "Comments”, cit. nota n 32, pp. 401 y ss.

${ }^{82}$ SMITH, Tom, "The use of public opinion data by the Attorney General's Commission on Pornography", American Association for Public Opinion Research, The Public Opinion Quarterly, t. 51, n ${ }^{\circ} 2$ (1987), pp. 249-267.

${ }^{83}$ WATANABE, "Real", cit. nota n 19, p. 200.

${ }^{84}$ WEGNER, "Teaching", cit. nota ${ }^{\circ} 42$, p. 2090.

${ }^{85}$ GUGLIELMI, "Virtual", cit. nota n 9, pp. 212-213.

${ }^{86}$ Según Akdeniz, el Dr. O'Brien explicó en 1983 lo que él denominó “ciclo de la pornografía infantil”, del siguiente modo: (1) la pornografía infantil se muestra a un niño con "fines educativos", (2) se realiza un intento de convencer a un niño que el sexo explícito es aceptable, incluso deseable, (3) el niño está convencido de que otros niños tienen una vida sexual activa y que tal conducta está bien, (4) la pornografía infantil desensibiliza al niño, reduce sus inhibiciones; (5) algunas de estas sesiones progresarán con actividades sexuales que involucran al niño; (6) se toman fotografías o videos de la actividad sexual, y, ( 7) este nuevo material se utiliza para atraer, seducir y obtener más víctimas menores. AKDENIZ, Internet Child Pornography, cit. nota ${ }^{\circ} 3$, pp. 4-5.

${ }^{87}$ Vid. PASTOR, Los delitos de posesión, cit. nota $\mathrm{n}^{\circ}$ 59, pp. 94-95. 
OXMAN, Nicolás. “Aspectos político-criminales y criminológicos de la criminalización de la posesión de pornografía infantil en Estados Unidos de Norteamérica".

a la cadena de reproducción criminal, sino que se está apuntando a la selección de la criminalidad visible, esto es, a la punta del iceberg del delito, al mismo tiempo se olvida que el verdadero problema está en canalizar la intervención penal hacia las formas más graves de criminalidad. Con todo, esta realidad demuestra la existencia de una nueva moral que reclama la punición de todas las formas de intervención posible en la sexualidad infantil, incluyendo aquellas conductas que no supongan inequívocamente la lesión o puesta en peligro de bienes jurídicos individuales y, al mismo tiempo, está exigiendo que el Derecho Penal se ocupe, también, de modo particularmente relevante de la prevención y promoción de la no realización de acciones que atenten contra la sexualidad infantil; por mínimas o equívocas que sean tales conductas, todas merecen ser objeto de reproche.

Con todo, resulta evidente que en la criminalización de la posesión de pornografía hay un uso instrumental o simbólico del Derecho Penal. En efecto, el legislador mediante esta técnica legal que busca el castigo de delitos de posesión cuya posibilidad de riesgo de lesión del bien jurídico resulta, por cierto, discutible, viene a plasmar en la sociedad una imagen normativa (mensaje) de lo que a nivel cultural o personal, ha de ser una conducta correcta en el ejercicio de la intimidad sexual, por parte de quien almacena imágenes pornográficas de menores. En tal sentido, no parece que la apelación genérica a un bien jurídico tan difuso como la "dignidad de los menores" pueda justificar racionalmente la vulneración o el quebrantamiento del principio de proporcionalidad y la prohibición de exceso. $^{88}$

2.3.4. La extensión de la argumentación del riesgo de comisión futura de un delito sexual para amparar la criminalización de la posesión de pornografía cuyo contenido no representa un menor real, sino que es el producto de imágenes virtuales o representaciones simuladas por adultos

Los cambios originados en la tecnología de las computadoras personales, junto a la posibilidad de intercambiar información por Internet, originan a mediados de los años noventa, del siglo pasado, una preocupación creciente por la gran cantidad de contenido pornográfico infantil que circulaba por la red virtual. Lo anterior, motivó la creación de una nueva ley cuya finalidad fue la prevención en este ámbito específico de la vida social (Child Pornography Prevention Act of 1996). ${ }^{89}$ Con esta norma se pretende abordar los retos derivados de la posibilidad de que cualquier persona, en la intimidad de su hogar, pueda crear, producir, trasmitir y poseer pornografía infantil, en especial, en lo que se refiere a la utilización de paquetes de software gráfico y animación por computadora como medios de manipulación o modificación de imágenes de seres humanos, donde muchas veces resulta indistinguible si las representaciones corresponden a personas reales, o bien, a individuos creados totalmente por la tecnología. ${ }^{90}$ En efecto, la nueva legislación incluye en la definición de pornografía infantil las imágenes creadas por computadoras, cuya

\footnotetext{
${ }^{88}$ Vid., DÍEZ RIPOLLÉS, José Luis, "El Derecho Penal Simbólico y los Efectos de la Pena", Actualidad Penal, $\mathrm{n}^{\circ} 1$ (2001), pp. 4-5. SILVA SÁNCHEZ, Jesús María, Aproximación al Derecho Penal Contemporáneo", Barcelona: Editorial Bosch, 2002. pp. 304 y ss.

${ }^{89}$ Vid. MOTA, "The U.S. Supreme Court", cit. nota ${ }^{\circ} 78$, pp. 85-88.

90 ARMAGH, "Virtual", cit. nota ${ }^{\circ}$ 34, pp. 1993 y 1994. SIEG, Robert, "Attempted possession of child pornography- a proposed approach for criminalizing possession of child pornographic images of unknown origin”, The University of Toledo Law Review, t. 36, ${ }^{\circ} 2$ (2005), p. 263.
} 


\section{Polit. crim. Vol. 6, No 12 (Diciembre 2011), Art. 2, pp. 252 - 294. [http://www.politicacriminal.cl/Vol_06/n_12/Vol6N12A2.pdf]}

descripción visual sea o parezca ser un menor involucrado en actividades sexuales explícitas. $^{91}$ En consecuencia, lo que se buscó incluir fue, por un lado, la denominada pornografía virtual, es decir, aquellas imágenes visuales creadas totalmente por programas computacionales, sin la participación de ningún menor real, como también, las representaciones visuales gráficas o de video que involucran actores profesionales jóvenes que aparentan ser menores. ${ }^{92}$

La nueva regulación fue objeto de numerosas críticas por parte de grupos intermedios, entre ellos, adquirió relevancia la denominada American Civil Liberties Union, la cual señaló que la prohibición de circulación de la pornografía virtual iba esencialmente en contra de la libertad de expresión $y$, por ende, su prohibición era inconstitucional, toda vez que el fundamento esgrimido por la Corte Suprema en el caso Ferber para prohibir la pornografía infantil fue, esencialmente, que ella involucraba la reproducción constante de un abuso sexual recaído en un menor real, lo que se extendía a la consideración de la incriminación de la posesión, toda vez que esta -en el razonamiento del caso Osborne- no solo involucraba una actividad cuya existencia favorecía el mercado de la producción y comercialización del material, sino que, también, bajo una lógica post-consumativa, la posesión del material presupone la existencia de un daño efectivo en contra de un ser humano, asunto que en la pornografía virtual o simulada no tiene lugar. ${ }^{93}$

Ahora bien, en el año 1999, la llamada Coalición por la Libertad de Expresión (asociación del Estado de California que protege los intereses de la industria pornográfica), ${ }^{94}$ presentó un recurso ante el Tribunal del Distrito Federal, en un litigio que fue conocido con el nombre de The Free Speech Coalition v. Reno; el objetivo era obtener la declaración de inconstitucionalidad de la ley de prevención de la pornografía infantil de 1996. El recurso fue fundamentado en que la expresión "parezca ser un menor involucrado en actividades sexuales explícitas", 95 utilizada por Código Penal Federal, era demasiado vaga e imprecisa y, además, daba pie a una limitación de la libertad de expresión vulnerando la primera enmienda, precisamente, porque podía ser interpretada para restringir la producción de pornografía infantil en la que adultos simulan ser menores de edad, o bien, derechamente los casos en que no se trata de personas reales, sino de imágenes creadas totalmente por computadora; como fundamento de su pretensión la Coalición invocó las decisiones de los

\footnotetext{
${ }^{91}$ En virtud de esta nueva legislación la Sección 18 del Código Penal Federal, en el parágrafo \&2258 (8), pasó a definir la pornografía infantil como cualquier representación visual de una conducta sexualmente explícita, incluyendo la fotografía, cine, video, dibujos, o imágenes generadas por computadora, o que hayan sido producidas por medios electrónicos, mecánicos u otros, cuando: (1) su producción implicó el uso o la participación de un menor en una conducta sexualmente explícita, o bien, (2) la representación visual es, o parece ser, la participación de un menor en una conducta sexualmente explícita, como también, los casos en que (3) la representación visual se ha creado, adaptado o modificado para parecer que se distingue a un menor en una conducta sexualmente explícita. SHUSTER, Lyndall, "Regulating virtual child pornography in the wake of Ashcroft v. Free speech coalition”, Denver University Law Review, $t .80, n^{\circ} 2$ (2002), pp. 434-435.

${ }^{92}$ Vid. MATTEI/CASEY/McGRATH, Investigating child exploitation, cit. nota $\mathrm{n}^{\circ}$ 5, p. 236. ARMAGH, "Virtual", cit. nota ${ }^{\circ} 34$, p. 1994.

${ }^{93}$ Vid. AKDENIZ, Internet Child Pornography, cit. nota ${ }^{\circ} 3$, p. 99.

${ }^{94}$ BERGELT, "Stimulation by simulation: is there really any difference between actual and virtual child pornography? The Supreme Courts gives child pornographers a new vehicle for satisfaction", Capital University Law Review (2003), p. 579.

${ }^{95}$ ADLER, "The perverse", cit. nota n³0, p. 244. ANDERSON, "Comments", cit. nota n 32, p. 403.
} 
OXMAN, Nicolás. “Aspectos político-criminales y criminológicos de la criminalización de la posesión de pornografía infantil en Estados Unidos de Norteamérica".

casos Miller y Ferber, como también, la referencia al caso Osborne, apelando, en consecuencia, a que no era posible prohibir la posesión de un material en el cual no se prueba la aparición de menores reales. ${ }^{96}$

La Corte de Distrito Federal negó el recurso, estimando que la ley no contenía disposiciones ambiguas, ni era inconstitucional y, por ende, desechó el argumento de limitación en la libertad de expresión que, según la Coalición, operaba desde el momento en que las autoridades restringieron la circulación y venta de material pornográfico infantil creado por computadora, o bien, desarrollado por adultos que simulan ser niños. La Corte de Distrito estimó que el fundamento de la prohibición de la distribución y posesión de este tipo de material está en que la norma federal busca contrarrestar los riesgos derivados del hecho de que la pornografía infantil, sea virtual o de cualquier tipo, pueda tener como espectadores eventuales o víctimas eventuales a menores de edad. ${ }^{97}$

La Coalición por la Libertad de Expresión apeló la sentencia ante la Novena Corte de Circuito de Apelaciones. Este Tribunal revocó el fallo, señalando que la ley de prevención de la pornografía de 1996 era inconstitucional. Para fundamentar su sentencia la Corte utilizó los siguientes argumentos: primero, que el legislador intentaba impedir el uso de la tecnología con fines perjudiciales, pero esto no puede efectuarse mediante la extensión del paradigma de ilegalidad de la pornografía infantil, según el cual se exige y se pretende evitar el daño a los derechos de menores reales; segundo, que tal argumento no puede ser considerado al mismo tiempo para prohibir una representación visual, únicamente sobre la base de que podría haber, eventualmente, un menor involucrado en una conducta sexualmente explícita; tercero, que las expresiones "parece ser" o "da la impresión", 98 son demasiado vagas e imprecisas, además, susceptibles de equívocos porque no existe ninguna norma que defina qué se ha querido decir con tales frases y, por ende, es posible que una persona con una inteligencia normal no entienda claramente los alcances de la conducta que se está prohibiendo; $y$, cuarto, no hay ningún antecedente científico acompañado al proceso que demuestre que la posesión de pornografía virtual involucre un posible peligro de afectación de un menor real, en orden a que pueda ser utilizada en la comisión de otros delitos sexuales. $^{99}$

La sentencia de la Novena Corte de Circuito de Apelación es la primera que va en contra de otros fallos que sí habían estimado como constitucional la prohibición de todo tipo de

\footnotetext{
${ }^{96}$ ANDERSON, “Comments”, cit. nota ${ }^{\circ} 32$, p. 418.

${ }^{97}$ En este caso, como en la apelación ante la Corte Suprema, el tribunal no se refiere a lo que se denomina "morphing", esto es, imágenes de niños involucrados en actividades sexuales creadas mediante la técnica de cortar y pegar partes de cuerpos de otros niños en las imágenes de adultos y viceversa. Al contrario, la materia objeto en la decisión del caso Ashcroft fue la pornografía virtual, es decir, el material que ha sido producido totalmente mediante ordenador gráfico. Ahora bien, la discusión en ambos casos se centra sobre la pregunta de quién es el victimizado con la imagen virtual, ya que como no se trata de un niño real, la privacidad de este no ha sido invadida, como tampoco a tendido lugar una agresión sexual. MATTEI/CASEY/McGRATH, Investigating child exploitation, cit. nota $\mathrm{n}^{\circ} 5$, p. 237.

98 "appears to be [a minor]" and "conveys the impression".

${ }^{99}$ WEISS, Karen, "But she was only a child. That is obscene!" the unconstitutionality of past and present attempts to ban virtual child pornography and the obscenity alternative", George Washington Law Review, $t$. $70, \mathrm{n}^{\circ} 1$ (2002), pp. 239-240.
} 


\section{Polit. crim. Vol. 6, No 12 (Diciembre 2011), Art. 2, pp. 252 - 294. [http://www.politicacriminal.cl/Vol_06/n_12/Vol6N12A2.pdf]}

pornografía virtual, sobre la base del argumento de la necesidad del legislador de prevenir el riesgo de utilización del material en la realización de otros delitos sexuales futuros. Así, por ejemplo: a) United States v. Hilton; b) United States v. Acheson; c) United States $v$. Mento; d) United States v. Fox. ${ }^{100}$

Con estos antecedentes el Procurador General del Estado (John David Ashcroft) interpuso un recurso ante la Corte Suprema con la finalidad de revocar la sentencia de la Novena Corte de Circuito de Apelación, el caso se denominó Ashcroft v. The Free Speech Coalition (sentencia del 16 de abril de 2002). ${ }^{101}$ En este fallo la Corte Suprema señala, por un lado, que no es delito la pornografía infantil que no requiere en su elaboración de la intervención de un niño real y, por otro lado, que la actividad del programador virtual consistente en la utilización de un software creando una representación gráficas en tres dimensiones, tanto del niño como del acto sexual que realizará, a entera imaginación del programador, es una producción intelectual protegida por la libertad de expresión. ${ }^{102}$ Este tipo de creaciones, dice la Corte, a diferencia del caso Ferber no registran ningún delito y no lesionan los derechos de la víctimas en su producción $\mathrm{y}$, por ende, la distribución y posesión de tales materiales tampoco puede constituir un delito, desde el momento en que esta no es manifestación de la existencia de un abuso o agresión efectivamente consumada. ${ }^{103}$ Finalmente, la Corte reafirma la idea que no existe antecedente que pueda servir para comprobar que la existencia de imágenes de pornografía virtual esté asociada a su utilización posterior en la seducción de menores con fines de abuso sexual; en fin, si existe alguna vinculación únicamente sería una relación de causalidad contingente e indirecta. ${ }^{104}$

En respuesta a la decisión de la Corte Suprema, el Congreso de los Estados Unidos promulgó en el año 2003 la Ley de Protección y Prevención de la Obscenidad y Pornografía Infantil (Child Obscenity and Pornography Preventión of the Protect Act 2003). En virtud de esta normativa se introducen cambios al parágrafo 2256 (8) del Código Penal Federal, en la parte en que se define la pornografía infantil, incluyendo, expresamente dentro del concepto de representaciones visuales aquellas que han sido producidas por

\footnotetext{
${ }^{100}$ En todos estos casos se destaca la categórica mención a la necesidad de una legislación eficaz en la lucha y prevención de todo tipo de explotación sexual infantil. MOTA, "The U.S. Supreme Court", cit. nota n 78 , p. 90 y notas de pie de página ${ }^{\circ} 44,45$ y 46.

${ }^{101}$ United States Supreme Court, Ashcroft v. Free Speech Coalition, (00-795) 535 U.S. 234 (2002), disponible en el sitio web: http://www.law.cornell.edu/supct/html/00-795.ZS.html [visitado el 18.05.2010].

${ }^{102}$ En el Código Penal chileno sobre la base del art. 366 quinquies inciso $1^{\circ}$ del Código Penal que emplea la frase "hubieren sido utilizados menores", un sector de la doctrina señala que no es posible incluir este tipo de pornografía virtual. POLITOFF/MATUS/RAMÍREZ, Derecho Penal, cit. nota ${ }^{\circ} 16$, p. 286. Implícitamente, GARRIDO, Derecho Penal, cit. nota ${ }^{\circ} 16$, p. 403. Estima que no se justifica el castigo de la pornografía simulada (que denomina como técnica), ni tampoco el castigo de la pornografía virtual, pero si el de la pseudopornografía. MOLINA, Delitos de pornografia, cit. nota ${ }^{\circ} 16$, pp. 72-74. Por la exclusión de todo tipo de pornografía infantil distinta de aquella en que se utiliza a un menor real. SÁNCHEZ, Delito de almacenamiento, cit. nota $\mathrm{n}^{\circ} 16$, pp. 85-86.

${ }^{103}$ BARUCH, "Case", cit. nota n ${ }^{\circ} 11$, pp. 1080 y ss.

${ }^{104}$ GLADOWSKI, Alison, "Has the computer revolution placed our children in danger? A closer look at the child pornography prevention act of 1996", Cardozo Women's Law Journal, n 8:21 (2001), pp. 21 y ss. "When the objects of desire is not a child, but merely a combination of millions of computer pixels crafted by skilled artist, can the government ban this allegedly victimless creation?, CISNEROS, Dannielle, "Virtual Child” Pornography on the Internet: Virtual Victim?", Duke Law \& Technology Review, nº 23 (2002), p. 1.
} 
OXMAN, Nicolás. “Aspectos político-criminales y criminológicos de la criminalización de la posesión de pornografía infantil en Estados Unidos de Norteamérica".

medios electrónicos $\mathrm{y}$, en lo que se refiere a las imágenes generadas por computadora, en vez de la expresión "parece ser un menor" se incluyó la frase "que es o se confunde con la participación de un menor en una conducta sexualmente explícita". ${ }^{105}$

Contrario a lo que podría pensarse, la invocación del precedente jurisprudencial del caso Ahcroft v. The Free Speech Coalition, no significó la exigencia de un mayor estándar de prueba para la Fiscalía. En efecto, hasta el momento los tribunales se han conformado con la apreciación material de las imágenes o de las representaciones visuales en las que aparecen menores, dejando al jurado, mediante la incorporación material de la prueba al juicio oral, la valoración o apreciación sobre si lo introducido por inmediación es o no un menor real; la técnica de litigación a dado bastantes resultados frente a las alegaciones de las defensas de los acusados, que han asumido la carga de tener que probar (por inversión del onus probandi) que las imágenes aportadas por la Fiscalía no son reales. Lo anterior puede constatarse en dos procesos fallados por la Sexta y Décima Corte del Circuito de Apelaciones en el año 2003 (United States v. Kilmer y United States v. Deaton, respectivamente). ${ }^{106}$ Recientemente a fines de 2007, el criterio se asentó en la decisión de la Primera Corte de Circuito de Apelación en el caso United States v. Rodríguez-Pacheco, donde se afirmó que la Corte Suprema no ha señalado ninguna regla sobre la naturaleza de la prueba que debe rendir en el juicio la Fiscalía en orden a acreditar si se trata o no de un menor real y, por ende, es suficiente con la incorporación material de la evidencia y la apreciación que haga de ella el jurado sobre la base de las impresiones de los testigos y peritos. ${ }^{107}$

2.3.5. Excurso: breve referencia al reconocimiento expreso del principio de lesividad y los casos de error (defenses) en que puede incurrir el poseedor de pornografía infantil

El párrafo 2252 A (d), del Código Penal federal establece casos en los cuales el poseedor de pornografía infantil puede invocar defensas afirmativas en contra de la acusación. Al respecto se señalan que se aceptarán como tales, en contra de la acusación de infringir el apartado (a)(5) (posesión de material pornográfico), que el acusado alegue que poseía menos de tres imágenes de pornografía infantil, o bien, que inmediatamente y de buena fe, $\mathrm{y}$ sin retener o permitir que persona alguna, distinta de un organismo encargado del cumplimiento de la ley, tenga acceso a cualquier imagen o copia de ella y, finalmente, que haya tomado las medidas razonables para destruir todas las imágenes.

Como señala Akdeniz ${ }^{108}$ esta disposición establece un claro avance, ya que se reconocen casos en que es posible que el acusado recurra al argumento de falta de lesión efectiva de la norma (poseer menos de tres imágenes), como también a supuestos en los cuales no le fue posible enterarse de inmediato que lo descargado y almacenado en el computador correspondía a pornografía infantil, además, de contemplar los casos en que se ha colaborado con la acción de la justicia. La utilización de las referidas defensas y su acreditación en el juicio excluyen la posibilidad de sanción penal.

\footnotetext{
${ }^{105}$ CISNEROS, "Virtual Child", cit. nota n ${ }^{\circ} 104$, pp. 2 y ss.

${ }^{106}$ SLOCUM, "Virtual”, cit. nota ${ }^{\circ} 23$, pp. 662-664.

${ }^{107}$ Vid. AKDENIZ, Internet Child Pornography, cit. nota ${ }^{\circ} 3$, p. 114.

${ }^{108}$ Vid. AKDENIZ, Internet Child Pornography, cit. nota ${ }^{\circ} 3$, p. 128.
} 
En el derecho anglosajón las defensas indicadas se extienden a otros casos claramente controvertibles. Así, en el Reino Unido (Inglaterra y Gales, Escocia e Irlanda del Norte), donde la pornografía infantil comprende todas las fotografías indecentes o pseudofotografías, que contengan imágenes de niños menores de 18 años modificadas por computadora (incluyendo las películas y cualquier forma de video sean copias o negativos), es posible encontrar una serie de excepciones que pueden ser alegadas por la defensa para justificar la posesión, dentro de las cuales se encuentran la fotografías de personas mayores de 16 años de edad que el acusado razonablemente creyó que representaban a una persona mayor de dicha edad; los casos en que el acusado y la víctima (de 16 o 17 años de edad), estuvo casada con el ofensor o fue socio de esta en una unión civil, o bien, tiene con ella una relación estable al tiempo de la comisión del delito, además, de los casos en que hubo consentimiento de la víctima. ${ }^{109}$

\section{Comprobación criminológica del riesgo futuro de realización de una agresión sexual por parte del poseedor de pornografía infantil}

Hemos visto como el legislador justifica la criminalización de la pornografía infantil -real y virtual- en Estados Unidos por la existencia de un riesgo asociado a la comisión futura de otros delitos sexuales contra menores; la referida argumentación se opone a la tesis jurisprudencial que, según señalamos, ha asentado la doctrina que el citado riesgo no estaría comprobado científicamente $\mathrm{y}$, por ende, solo es posible sancionar la posesión de pornografía cuando ella se refiere a un abuso sexual realmente cometido, porque, con ello, se restringe y limita la cadena asociada a la producción, comercialización y difusión. Esta dicotomía nos lleva a la interesante cuestión de develar si la existencia de este delito de posesión es susceptible o no de ser legitimada a nivel criminológico, sobre la base del razonamiento esgrimido por el legislador.

Como veremos en los párrafos que siguen la criminología, dejando a un lado la crítica sobre la necesidad de recurrir a criterios empíricos para demostrar la validez de una norma penal, nos introduce a importantes cuestiones metodológicas derivadas de la determinación de los riesgos de reincidencia en delincuentes sexuales. Asunto de la más reciente actualidad, pues, es posible constatar la adaptación de diversos métodos de predicción, cuya aplicación se muestra como generalizada. Particular importancia tiene una postura criminológica que, a partir de una evolución posterior de la teoría de la asociación diferencial, intenta en sede $\operatorname{cognitiva}^{110} \mathrm{y}$, sobre la base de la implementación de predictores dinámicos específicos de

109 SALEH, Fabian; GRUDZINSKAS, Albert; BRADFORD, Jhon; BRODSKY, Daniel, Sex offenders: Identification, risk assessment, treatment, and legal issue, New York: Oxford University Press, 2009, p. 306.

${ }^{110}$ Uno de los exponentes fundacionales de esta teoría es Albert Bandura quien señala al delito como una consecuencia del aprendizaje social, que este debe estudiarse sobre la base del descubrimiento de los patrones exógenos que originan la tendencia a la agresión, como también, desde la averiguación de los fenómenos que provocan que las personas decidan cometer un delito $\mathrm{y}$, finalmente, lo que hace que el individuo se mantenga en tal conducta. En tal sentido, el origen del delito (entendido como agresión), es consecuencia del aprendizaje y la ejecución reforzada de determinadas conductas, a lo que se le unen determinantes estructurales. Ahora bien, existen factores que provocan la instigación de la agresión (la realización del delito), entre los cuales es posible encontrar influencias del medio relacionadas con la inhibición, facilitación, activación y acrecentamiento de determinadas conductas aprendidas, entre otros factores. Finalmente, lo que hace que una persona se mantenga en el delito se explicaría por la existencia de reforzadores de la agresión, 
OXMAN, Nicolás. "Aspectos político-criminales y criminológicos de la criminalización de la posesión de pornografía infantil en Estados Unidos de Norteamérica”.

riesgo -según el estudio de los patrones de la personalidad modificables y del tipo de delito cometido-, prevenir y detectar los aspectos sobre los cuales debe concentrarse el tratamiento. Este mecanismo permitiría identificar cuándo estamos ante un sujeto peligroso. Pero lo que resulta asimismo importante, es la determinación no solo de tal "estado", sino que, también, la definición de los factores que pueden demostrar la vinculación precisa que puede existir entre la conducta de descarga y posesión de pornografía infantil por Internet y la comisión de una agresión sexual futura.

Ahora bien, para una mejor comprensión de lo anterior, se hace necesario explicar y describir previamente los denominados modelos estáticos de determinación de riesgo criminal, ya que constituyen el método más utilizado actualmente en Estados Unidos.

Un último aspecto sobre el cual llamaremos la atención es la descripción de estudios empíricos aplicados que, a partir de la estadística y el seguimiento a personas sujetas a medidas de control extrapenitenciario, señalan interesantes resultados en torno a la incidencia precisa de la posesión de pornografía infantil en la realización de delitos sexuales futuros.

\subsection{Los métodos estáticos de predicción de riesgo criminal en delincuentes sexuales}

Los métodos estáticos de predicción de riesgo criminal $^{111}$ comenzaron a aplicarse, según Harcourt, ${ }^{112}$ en el Derecho Penal penitenciario en Estados Unidos a fines de 1928, cuando Burgess y Laune completaron un estudio de predicción de la reincidencia en la prisión de Illinois, con el objetivo de abordar la determinación del nivel de éxito o fracaso eventual del otorgamiento de libertad condicional. El citado autor afirma que en la actualidad los índices de discriminación de factores de riesgo ${ }^{113}$ son utilizados como herramientas para

los que pueden ser externos (recompensas tangibles, sociales, de status), vicarios (recompensa observada, o bien, la aceptación del castigo observado), autoreforzamiento (autocastigo, autorecompensa, neutralización del autocastigo, justificación moral, comparación ventajosa, difusión de la responsabilidad, deshumanización de la víctima, atribución de culpa a la víctima, malinterpretación de las consecuencias). Vid. BANDURA, Albert, “Análisis del aprendizaje social de la agresión", Modificación de la conducta: Análisis de la agresión y la delincuencia. Biblioteca técnica de psicología, México: Ed. Trillas, 1980. pp. 310-311.

${ }^{111}$ El sistema estático de medición de factores de riesgo está destinado a efectuar predicciones de reincidencia y peligrosidad a largo plazo en base al historial previo del delincuente. Para el diagnóstico se incluyen como indicadores relevantes los antecedentes penales y clínicos previos, especialmente, el tipo de delito por el cual se impuso la primera condena y edad en que se cometió el primer hecho delictual, además, se pondera la existencia de relaciones de afectividad entre el agresor y la víctima, asignado un puntaje diferente dependiendo si el delincuente sexual era o no un extraño para el ofendido y si este era un niño o un adulto. Este método debe su nombre y crítica al hecho de que no permite evaluar los cambios de los niveles de riesgo en el tiempo, dado que el pasado del autor del delito permanece inalterable o estático. Vid. CRAIG, Leam; BROWNE, Kevin; BEECH, Anthony, Assessing risk in sex offenders. A practitioner's guide, Southern Gate, Chichester: Ed., Wiley \& Sons Ltda., 2008, p. 55.

${ }^{112}$ HARCOURT, Bernard, Against prediction: Profiling, policing, and punishing in an actuarial age, Chicago: University of Chicago Press, 2007, pp. 1-2.

113 "La expresión factores de riesgo se emplea en la investigación sobre carreras criminales para hacer referencia a aquellos elementos y variables personales o sociales cuya presencia hace más probable el mantenimiento de la actividad delictiva de un sujeto". PÉREZ RAMÍREZ, Meritxell; REDONDO ILLESCAS, Santiago; MARTÍNEZ GARCÍA, Marian, et. al., "Predicción de riesgo de reincidencia en agresiones sexuales", Psicothema, vol. 20, n² (2008), p. 206. 


\section{Polit. crim. Vol. 6, № 12 (Diciembre 2011), Art. 2, pp. 252 - 294. [http://www.politicacriminal.cl/Vol_06/n_12/Vol6N12A2.pdf]}

identificar en el plano penal, a quién buscar, en qué casos castigar con una mayor pena, o bien, la forma de administrar la justicia penal. Tales métodos de predicción cuentan con el parecer de la ciudadanía y de las autoridades por estimarse que facilitan la maximización de los recursos económicos del Estado, debido a que se considera que la información contenida en ellos es fiable, permitiendo a la Policía concentrar su atención en los posibles criminales futuros y a los jueces determinar legalmente la duración efectiva de las penas privativas de libertad, derivadas de la aplicación de las medidas de control accesorias a la pena. Hay una suerte de consenso generalizado, según el cual, la sociedad no está dispuesta a asumir los costes que significa la reincidencia.

El mismo autor postula decididamente que los métodos actuariales deben ser desechados a favor de la selección aleatoria, debiendo preferirse los estudios fundamentados en métodos estadísticos sobre la base de datos empíricos asociados a la observación de personas que se encuentran en libertad, con una selección de muestras al azar, porque es la única manera de alcanzar datos sobre los reales delitos que se cometen en la sociedad. "Las personas que se encuentran en una situación similar deben tener la misma probabilidad de ser detenidos cuando delinquen, independientemente de su raza, etnia, género o clase", que son los perfiles "contaminados" sobre los cuales se concentra este método actuarial de predicción de riesgos, ya que se basa en la recopilación de datos estáticos sobre el pasado criminal, donde los antecedentes penales previos son el dato preponderante. De este modo, el método aleatorio permitiría cerrar la puerta a los pronósticos actuales de peligrosidad futura, en concreto, en lo que a la duración de las sanciones penales se refiere. ${ }^{11}$

Ahora bien, los métodos estáticos de determinación de riesgo no siendo específicos ni diferenciados según el tipo de delincuencia sexual, intentan, pese a ello, predecir la posible comisión futura de otros delitos sexuales, partiendo de la base, presumiblemente demostrada en términos científicos, que los delincuentes sexuales con antecedentes penales previos, tienen mayores probabilidades de reincidir. ${ }^{115}$ En tal sentido, se constata el uso generalizado y asentado de la denominada escala rápida de evaluación de riesgo de reincidencia para delitos sexuales (rapid risk assessment for sex offense recidivism scale),

\footnotetext{
${ }^{114}$ HARCOURT, Against prediction, cit. nota ${ }^{\circ} 112$, p. 5.

${ }^{115}$ En 1999 se desarrolló uno de los instrumentos actuariales más usados para la evaluación de riesgos de reincidencia para delincuentes sexuales en el Estado de Virginia. Para su elaboración, se tomó una muestra aleatoria de 579 delincuentes sexuales liberados de la cárcel entre 1990 y 1993. La Comisión de Sentencias, tras dos años de revisión y análisis de los datos, elaboró un sistema de riesgo actuarial que comenzó a funcionar el 01 de julio de $2001 \mathrm{y}$, desde entonces, se ha incorporado como un sistema directriz en la determinación de la condena de delincuentes sexuales. Este instrumento utiliza una matriz de conjunto para producir una puntuación numérica cuyo objetivo es clasificar a las personas condenadas en cuatro niveles de riesgo. Para calcular la puntuación los jueces y los oficiales de sentencia hacen referencia a una hoja simple en la que se completan espacios en blanco. Así, por ejemplo, en los casos de violación, la matriz tiene en cuenta ocho factores concernientes a la víctima y al victimario, incluyendo la edad, la educación, el empleo que registra el sentenciado, su relación con la víctima, el lugar de realización del delito y sus antecedentes penales anteriores, incluyendo una pregunta sobre la posible naturaleza agravada de la agresión sexual. De este modo, se determina un resultado que equivale al índice de riesgo de reincidencia. Según Harcourt este sistema se ha ajustado para asegurar que nadie obtenga una puntuación inferior a 28 puntos, con ello, se garantiza que no exista una recomendación de rebaja de pena, porque el resultado menor equivale al mantenimiento de la pena, pero nunca se traduce en una reducción. HARCOURT, Against prediction, cit. nota $\mathrm{n}^{\circ} 112, \mathrm{p} .11$.
} 
OXMAN, Nicolás. “Aspectos político-criminales y criminológicos de la criminalización de la posesión de pornografía infantil en Estados Unidos de Norteamérica”.

que establece cuatro indicadores o variables: a) el número de delitos sexuales cometidos con anterioridad; b) edad al tiempo de liberación en relación a primitiva condena (más o menos de 25 años); c) la temprana orientación hacia víctimas masculinas; y, d) la orientación previa hacia víctimas no vinculadas afectiva ni parentalmente con el delincuente. El número de factores concurrentes asigna un puntaje, lo que determina el índice de riesgo; este método actuarial es considerado un predictor más seguro que la evaluación clínica y su objeto es extender al máximo la duración real de las sentencias. ${ }^{116}$

Tal sistema de predicción de riesgo de reincidencia en delincuentes sexuales ha sido criticado, por su escasa flexibilidad. En efecto, se señala que tiene por única finalidad la neutralización del delincuente, sin atender a la eventual reevaluación del índice de riesgo que, en algunos casos, podría mostrar un cambio con ocasión de la desaparición futura de algunos de los factores originales no considerados en la predicción original. Además, según Craig, Browne y Beech ${ }^{117}$ muchas escalas de riesgo basadas en factores estáticos tienen una validez limitada en el caso de delincuentes que por primera vez cometen un delito sexual, como también, respecto de quienes lo realizaron de modo ocasional o en respuesta a orientaciones sádicas.

En el plano político-criminal, desde hace un tiempo se viene diciendo que en Estados Unidos el debate en torno a la inocuización como fin de la pena, jamás ha sido abandonado ni tampoco obedece a una cuestión casual del último tiempo, siendo posible advertir un desencanto generalizado en torno a la ideología de la resocialización y, además, una obsesión por la seguridad y por la neutralización de los delincuentes sexuales mediante el abuso de la pena indeterminada. En tal sentido, Silva Sánchez señala que "en los años noventa se empieza a difundir un modelo legislativo distinto, que expresa de modo claro el abandono de la anterior orientación (pretendidamente) terapéutica y la acogida de una línea claramente punitivista e inocuizadora". ${ }^{118}$ En efecto, la inocuización (incapacitation) es entendida como el medio más directo para prevenir o hacer imposible que personas peligrosas, particularmente, delincuentes violentos cometan delitos en el futuro. ${ }^{119} \mathrm{Al}$ respecto, Harcourt ${ }^{120}$ critica duramente el hecho que la determinación de la condena criminal esté relacionada con una serie de medidas adicionales al cumplimiento efectivo de la pena cuya duración depende de los métodos actuariales basados en la predicción de riesgo criminal, porque, en el fondo, han desplazado a las teorías de la pena, sustentadas en el estándar democrático de la retribución, la disuasión y el principio de lesividad o ponderación del daño.

116 JANUS, Eric; PRENTKLY, Robert, "Forensic use of actuarial risk assessment with sex offender: accuracy, admissibility and accountability”, American Criminal Law Review, n 40 (2003), pp. 1469-1470.

${ }_{117}^{117}$ CRAIG/BROWNE/BEECH, Assessing risk, cit. nota n ${ }^{\circ} 111$, pp. 67-68.

${ }^{118}$ SILVA SÁNCHEZ, Jesús María, "El retorno a la inocuización. El caso de las reacciones jurídico-penales a los delincuentes sexuales violentos", en: Arroyo Zapatero, Luis; Verdugo Gómez de la Torre, Ignacio (Dirs.), Homenaje al Dr. Marino Barbero Santos in memoriam, t. I, Castilla La Mancha: Ed. Universidad Castilla la Mancha, 2001. p. 703. Sobre el internamiento indeterminado, la abolición del parole y la castración química para los denominados sexual predators en Estados Unidos. ROBLES PLANAS, Ricardo, "Sexual Predators. Estrategías y límites al derecho penal de la peligrosidad", InDret: Revista para el Análisis del Derecho, ${ }^{\circ} 4$ (2007), pp. 5 y ss.

${ }_{119}$ ROBINSON, Criminal law, cit. nota ${ }^{\circ} 8$, pp. 89 y ss.

${ }^{120}$ HARCOURT, Against prediction, cit. nota ${ }^{\circ} 112$, p. 188. 


\section{Polit. crim. Vol. 6, No 12 (Diciembre 2011), Art. 2, pp. 252 - 294. \\ [http://www.politicacriminal.cl/Vol_06/n_12/Vol6N12A2.pdf]}

\subsection{El método dinámico específico de predicción de riesgos para los poseedores de pornografía infantil diseñado por Malesky, Ennis y Gress}

En oposición al estudio basado en los antecedentes penales previos, un reciente estudio teórico publicado en el año 2009 por Maleski, Ennis y Gress ${ }^{121}$-el cual esperan complementar empíricamente en el futuro-sostiene que los predictores actuariales estáticos de riesgo no son un método válido para evaluar ni pronosticar el comportamiento futuro de un delincuente condenado o sujeto a observación por posesión de material pornográfico infantil, ya que tales instrumentos de evaluación han sido elaborados para los delincuentes sexuales violentos y, por ende, se carece en la actualidad de una metodología específica que, sobre la base de elementos dinámicos, ${ }^{122}$ permita establecer no solo que una persona tiene posibilidades de reincidir (como ocurre con los métodos actuariales fundados en la ponderación de la reincidencia como factor desencadenante del riesgo), sino que, también, determinar sobre la base del estudio de los patrones dinámicos de comportamiento, en qué momento una persona condenada por posesión de material pornográfico infantil puede cruzar la línea hacia la realización de un delito sexual de contacto.

Ahora bien, los métodos de predicción de riesgo criminal basados en factores dinámicos, son un intento de superación o complementación de los sistemas actuariales estáticos. Ello, porque la intención es mejorar y hacer aún más precisa la predicción del riesgo de reincidencia de delincuentes sexuales violentos integrando la evaluación clínica terapéutica. En el fondo, se busca revalorar la función rehabilitadora, sobre la base de la determinación de los factores que pueden ser objeto de cambio mediante el tratamiento (por ejemplo, conductas sexuales desviadas, problemas socio-afectivos, problemas de autorregulación sexual, etc.); sin embargo, la valoración crítica obliga a poner de relieve el hecho que, en realidad, no se sabe mucho ni existe consenso científico -a diferencia de lo que ocurre con los métodos actuariales- acerca de cuáles son las características precisas de la personalidad que deben cambiar a fin de reducir el factor de riesgo, como tampoco, hay certeza sobre qué cambios en los factores dinámicos hacen incrementarla peligrosidad, como tampoco, respecto de los métodos para medir la variación. Pese a lo anterior, como anotan Craig, Browe y Beech, se ha masificado el uso de estos factores dinámicos y, entre ellos, destaca como instrumento el denominado: Sexual Violence Risk Assessment-20 (SVR-20) como parte de un enfoque global estructurado de evaluación en combinación con los sistemas

${ }^{121}$ MALESKY, Alvin; ENNIS, Lian; GRESS, Carmen. "Child Pornography and The Internet”, en: Saleh, Fabian; Grudzinkas, Albert; Bradford, Jhon; Brodky, Daniel, (Dirs.), Sex Offenders: identification, risk assessment, treatment, and legal issues, New York: Oxford University Press, 2009, p. 312.

${ }^{122}$ Los sistemas de medición de factores de riesgo dinámicos son aquellos basados en elementos o variables "duraderas" relacionadas con la probabilidad de cometer un delito en el futuro, pero que no obstante lo anterior, se entienden modificables mediante la intervención clínica terapéutica. El sistema dinámico se divide en el uso de factores estables y agudos. Los factores estables son aquellas variables que constituyen características relativamente persistentes en el delincuente y que pueden eventualmente estar sujetos a modificaciones en largos períodos de observación, según se modifiquen los niveles de autorresponsabilidad, distorsión cognitiva y excitación sexual. Por su parte, los factores agudos o críticos son aquellas variables que sufren rápido cambio, es decir, se trata de características circunstanciales que pueden modificarse en días $u$ horas, entre las que se mencionan el abuso de sustancias tóxicas, el aislamiento, conductas asociadas a la búsqueda de víctimas y estados emocionales negativos; la mayor o menor presencia de tales elementos incrementa o disminuye significativamente la predicción de riesgo de reincidencia. CRAIG/BROWNE/BEECH, Assessing risk, cit. nota n ${ }^{\circ} 111$, p. 55. 
OXMAN, Nicolás. “Aspectos político-criminales y criminológicos de la criminalización de la posesión de pornografía infantil en Estados Unidos de Norteamérica”.

actuariales para mejorar la precisión. ${ }^{123}$ Este instrumento se encuentra adaptado al castellano, ${ }^{124}$ cuya aplicación en Barcelona concluye que tiene una tasa de $78,5 \%$ de clasificaciones correctas en el pronóstico de la reincidencia sexual. ${ }^{125}$

Ahora bien, como hemos podido observar, los métodos estáticos y dinámicos de predicción de riesgos están destinados a determinar el factor de reincidencia en otro delito sexual violento, pero no han sido creados para fijar la relación entre la posesión de material pornográfico y la realización futura de un delito sexual de contacto.

En conocimiento de lo anterior, Maleski, Ennis y Gress proponen, hasta el momento a nivel teórico, la aplicación de un método de comprobación dinámica de riesgo específico para personas condenadas por posesión de material pornográfico sobre la base de la combinación de la evaluación de cuatro factores: primero, la autorregulación sexual; segundo, los problemas generales de autorregulación; tercero, el déficit de intimidad y funcionamiento interpersonal; y, cuarto, las distorsiones cognitivas e influencias sociales negativas. $^{126}$

En cuanto a la autorregulación sexual, ella se vincula con el uso de la sexualidad como medio de evitación del estrés, lo que se manifiesta en conductas como, por ejemplo, la utilización de la pornografía infantil como mecanismo de evitación o alteración de los estados de ánimo negativos, o bien, como una forma de satisfacción de las fantasías sexuales. En lo referente a los problemas generales de autorregulación, los citados autores explican que ella está relacionada con la incapacidad de resolver problemas, planificar y regular sus impulsos en la vida diaria a fin de alcanzar objetivos a largo plazo. En consecuencia, la pornografía infantil se convierte para este tipo de personas en una forma de satisfacción sexual inmediata. El déficit de intimidad y funcionamiento interpersonal es la constatación que el evaluado en su vida diaria elige parejas sexuales inapropiadas como resultado de la soledad emocional y los intentos fallidos por lograr una intimidad adecuada, lo que se manifiesta, en el sentimiento de rechazo anticipado por parte de parejas sexuales

${ }^{123}$ CRAIG/BROWNE/BEECH, Assessing risk, cit. nota ${ }^{\circ} 111$, pp. 91 y 92.

${ }^{124}$ En la versión castellana se le ha denominado: "Manual de valoración del riesgo de violencia sexual", fue adaptado y aplicado en Barcelona (España), por el Grupo de estudios avanzados en Violencia (GEAV), de la Universidad de Barcelona en el año 2005. Además, hemos tenido a la vista un estudio empírico del año 2008, sobre determinación precisa de reincidencia en delincuentes sexuales aplicado en el Centro Penitenciario de Brians de Barcelona, tomando como muestra los sujetos condenados por agresiones sexuales desde 1991 a 2002. Este estudio desarrollado por Pérez, Redondo y Martínez, aplicó, precisamente, los 20 factores de riesgo de reincidencia del SVR-20, entre los cuales se incluyen: 1. Funcionamiento psicosocial, que incorpora 11 factores de riesgo referentes al funcionamiento sexual: a) presencia de desviación sexual; b) haber sido víctima de abuso sexual en la infancia; c) psicopatías, trastornos mentales graves; d) abuso de drogas; e) ideación suicida o homicida; f) problemas al establecer o mantener relaciones de pareja estables; g) problemas para mantener un trabajo estable. 2. Delitos sexuales, que agrupa 7 ítems: a) frecuencia de delitos sexuales graves; b) tipologías sexuales diversas; c) gravedad del daño físico o psicológico ocasionado a la víctima; d) utilización de armas o amenazas de muerte; e) progresión en la frecuencia o intensidad de los delitos; f) minimización extrema de las agresiones sexuales; $y, g$ ) actitudes que apoyan o toleran las agresiones sexuales. 3. Planes de futuro, que incluye 2 ítems: a) tendencia a realizar planes poco realistas; y, b) pesimismo. PÉREZ RAMÍREZ/REDONDO/MARTÍNEZ et. al., "Predicción", cit. nota n 113, pp. 206-207.

125 PÉREZ RAMÍREZ/REDONDO/MARTÍNEZ et. al., "Predicción”, cit. nota n 113, p. 210.

126 MALESKY, "Child Pornography”, cit. nota n 121, p. 313. 


\section{Polit. crim. Vol. 6, No 12 (Diciembre 2011), Art. 2, pp. 252 - 294. [http://www.politicacriminal.cl/Vol_06/n_12/Vol6N12A2.pdf]}

con las cuales se requiere efectuar esfuerzos de vinculación interpersonal, en consecuencia, las relaciones que puede otorgar la pornografía infantil a través de Internet, como también, las interrelaciones asociadas a fantasías sexuales que el autor crea con los niños representados en las imágenes pornográficas, sirven para compensar las insatisfactorias relaciones interpersonales del delincuente en su vida off-line. ${ }^{127}$

En lo que respecta a las distorsiones cognitivas, ellas consisten en creencias sobre la sexualidad y el comportamiento sexual que los individuos poseedores de pornografía infantil utilizan para justificar y desinhibir sus conductas, en concreto, es la asimilación del pensamiento que otras personas efectúan comportamientos sexuales más graves y, por ende, internamente la conducta se refuerza bajo el prisma que se trata de un delito "sin víctima" que les permite, incluso, evitar la realización de delitos de contacto sexual con menores. Finalmente, las influencias sociales negativas, se definen como la asociación con otras personas que tienen idénticas tendencias criminales, lo que los autores del estudio estiman como el predictor más determinante en el riesgo de reincidencia futura y en la realización eventual de delitos de contacto sexual porque a través del ingreso a estas comunidades el individuo no se siente aislado ni diferente, lo que posibilita la obtención de apoyo emocional y motivacional.

\subsection{La comprobación del riesgo de comisión de un delito sexual de contacto en el estudio estadístico de Seto y Eke}

Hasta antes de la realización de la investigación de Seto y Eke ${ }^{128}$ se desconocía en la literatura científica la probabilidad estadística ${ }^{129}$ de que una persona condenada por posesión de material pornográfico infantil pudiere cometer en el futuro cercano algún tipo de agresión sexual, ya sea en contra de menores de edad o de otras personas adultas. Sin embargo, sobre la base un estudio empírico de campo, efectuado en Canadá, se plantearon la posibilidad de desarrollar una estadística de predicción de riesgos futuros de agresiones sexuales. Para poder efectuar lo anterior, observaron durante 2 años y 6 meses a 201 condenados por posesión de material pornográfico infantil, ${ }^{130}$ determinado preliminarmente que el 17\% volvió a cometer algún delito - no necesariamente sexual-durante el período de seguimiento. ${ }^{131}$ Además, se establecieron potenciales factores de predicción de delitos

\footnotetext{
127 MALESKY, “Child Pornography”, cit. nota n 121, pp. 314-319.

128 SETO, Michael; EKE, Angela, "The criminal histories and later offending of child pornography offenders", Sexual Abuse: A Journal of Research and Treatment, $t .17, \mathrm{n}^{\circ} 2$ (2005), p. 201.

${ }^{129}$ El método estadístico, actúa sobre la base de la utilización de tablas de predicción para elaborar desde ahí un cálculo de probabilidades, comparando las características de la muestra observable con las que aparecen en la tabla, asignándoles un porcentaje. El resultado global en comparación con el total de la muestra otorga un pronóstico. Vid. ROCA AGAPITO, Luis, El sistema de sanciones en el Derecho Penal español, Barcelona: Bosch Editor, 2007, pp. 376 y 377.

${ }^{130}$ SETO/EKE, "The criminal", cit. nota $n^{\circ} 128$, p. 201.

${ }^{131}$ La base de datos se extrajo del registro de delincuentes sexuales de Ontario, el cual existe en Canadá desde abril de 2001. Este sistema público de información, incluso a través de Internet, permite a todo quien tenga acceso a la red obtener información sobre los datos completos de los delincuentes sexuales condenados, incluyendo, a quienes se encuentran en probation o en parole, detallando su nombre completo, fecha de nacimiento, fotografía, dirección, antecedentes penales y descripción física (talla, peso, tatuajes, cicatrices, color de piel, pelo y ojos). Estas leyes tienen su origen en Estados Unidos, donde la obligación de notificación y registro comunitario de delincuentes sexuales, son utilizadas como estrategias de control social desde 1994
} 
OXMAN, Nicolás. “Aspectos político-criminales y criminológicos de la criminalización de la posesión de pornografía infantil en Estados Unidos de Norteamérica”.

sexuales futuros, sobre la base que un 56\% tenía antecedentes penales y el $15 \%$ correspondía a delitos asociados a la pornografía infantil. Lo anterior, demostraría que la creencia que los delincuentes que registran antecedentes penales por agresiones sexuales de contacto son más propensos a cometer otro delito sexual, o bien, cualquier otro tipo de delito.

La investigación realizada por Seto y Eke intenta responder a las interrogantes asociadas a la existencia de predictores de riesgo de comisión de delitos sexuales futuros en personas condenadas por posesión de material pornográfico infantil $\mathrm{y}$, además, establecer factores que permitirían eventualmente distinguir peligros asociados a la posibilidad de reincidencia delictual en general, teniendo en consideración los antecedentes penales previos y la versatilidad de los tipos de delitos cometidos. ${ }^{132}$

El primer dato del estudio fue extraído de la consideración del número de personas con antecedentes penales y el tipo de delitos que habían cometido con anterioridad a la condena o acusación por posesión de material pornográfico infantil. La muestra reveló que 112 personas, lo que equivale al $56 \%$, tenía antecedentes penales. Ahora bien, en este grupo el $45 \%$ registraba condenas o acusaciones previas por delitos no violentos y el 30\% por delitos violentos; constatándose que el 17\% había cometido un delito sexual sin contacto y, por último, que el 15\% registraba una condena o acusación por delitos asociados a la pornografía infantil. ${ }^{133}$

Para determinar el nivel de riesgo se consideró para la muestra la época que mediaba entre la comisión del delito y el período de observación (como se dijo, aproximadamente, 2 años y 6 meses), restando en todos los casos el tiempo en que la persona estuvo privada de libertad, por no ser parte del método y no tener la "posibilidad teórica" de cometer un nuevo delito. El tiempo de observación preciso fue de 29,7 meses, con una desviación estándar de 14,2 meses, en un rango que iba de los 15 días a los 6,2 años (la amplitud del rango se debe a que dentro de la muestra algunas personas habían cometido delitos de

y son conocidas como la ley Megan y la ley Jacob, en recuerdo de los menores Megan Kanka y Jacobs Wetterling, víctimas de abusos sexuales y asesinato. LOGAN, Wayne, "Sex offender registration and community notification: past, present, and future", New England Journal on criminal and civil confinement, $t$. $34, n^{\circ} 3$ (2007), p. 5.

${ }^{132}$ La muestra estuvo compuesta por 201 personas condenadas por posesión de material pornográfico infantil, con una edad al tiempo de comisión del delito que oscilaba entre los 19 a los 76 años (promedio: 38,3, con una desviación estándar de 12,2). Ahora dentro de las personas con antecedentes penales previos, la edad de la primera condena variaba entre un rango que iba desde los 13 a los 76 años (promedio: 32,0, con una desviación estándar de 13,2). Vid. SETO/EKE, “The criminal”, cit. nota n 128, pp. 203-204.

${ }^{133}$ Para le elaboración del estudio se tomaron en consideración todas las nuevas acusaciones o condenas por delitos sexuales consignadas en el registro público desde el 27 de abril de 2004. La expresión "delito no violento", incluyó acusaciones y condenas por delitos que no implican un contacto directo con una persona, por ejemplo, el hurto, las defraudaciones, la posesión de narcóticos, además, de la pornografía infantil y los delitos sexuales sin contacto con la víctima como la provocación sexual. Por su lado, el concepto de delito violento comprendió las acusaciones y condenas por delitos sexuales que involucren contacto físico con la víctima $\mathrm{y}$, en general, todo delito que conllevare acometimiento material sobre la víctima. Sin perjuicio de ello, se comprende como categorías especiales de delitos sexuales violentos y no violentos (posesión, distribución o producción de pornografía infantil y faltas relativas a la prostitución), según hubo o no contacto sexual directo con la víctima y, finalmente, como categoría especial la pornografía infantil. SETO/EKE, "The criminal", cit. nota $n^{\circ} 126$, pp. 204-205. 
posesión de material pornográfico infantil antes de la creación del registro de delincuentes sexuales en el año 2001). En este grupo se determinó que dos tercios de las 201 personas (135), presentaban exclusivamente antecedentes por delitos asociados a la pornografía infantil. El tercio restante, registraba previamente otros delitos con un promedio de 4,3\% condenas o acusaciones por delitos no violentos (variación estándar de 6,8 , en un rango que iba de 1 a 43 delitos). Un 3,8\% registraba antecedentes por delitos violentos (desviación estándar de 5,7\%, en un rango de 0 a 36 delitos), 2,3\% personas tenían antecedentes por delitos con contacto sexual (variación estándar de 3,7\%, en un rango de 0 a 19 delitos), y un $4,4 \%$ poseía cargos por delitos sin contacto sexual (variación estándar de $7,4 \%$ con un rango de 1 a 42 delitos). La amplitud de variación se explica por el hecho de que 4 delincuentes poseía una gran cantidad de antecedentes penales. ${ }^{134}$

En lo que se refiere a la comisión de delitos con posterioridad a la condena o acusación de un delito de pornografía infantil, Seto y $\mathrm{Eke}^{135}$ constataron que 34 personas del total de 201 antes indicado -lo que equivalía al $17 \%$ de la muestra reincidió en un delito, no necesariamente sexual- durante el período total de seguimiento que equivalió a 2,5 años. Con todo, restando 5 personas privadas de libertad (de las cuales 4 cometieron delitos en prisión y de éstos 2 fueron acusados por posesión de material pornográfico infantil, 1 por delitos no violentos y 1 por un nuevo delito violento de contacto sexual con otro recluso), la muestra arrojó un total observable de 29 personas en libertad de la cuales solo 11 reincidieron por delitos asociados a la posesión de material pornográfico infantil, es decir, una tasa del $6 \%$ de la muestra total de seguimiento. ${ }^{136}$

Lo que interesa a nuestro estudio es que solamente uno de los delincuentes condenados por pornografía infantil cometió un delito sexual de contacto, sin embargo, pese a reconocer que este dato podría variar si se aumentara el período de observación, afirman, categóricamente, que su "hallazgo está en contradicción con la suposición de que las personas que cometen delitos de pornografía infantil tienen un alto riesgo de cometer otros delitos de contacto sexual". ${ }^{137}$ Precisamente, estos investigadores complementaron posteriormente la investigación en el año 2006, ampliando el período de observación de 2,5 a 3,6 años, conservado siempre la muestra original. En esta extensión de la investigación se constató que 13 de las personas condenadas por pornografía infantil $(6,6 \%)$, cometieron un delito sexual de contacto durante el período total de seguimiento

\footnotetext{
${ }^{134}$ SETO/EKE, “The criminal”, cit. nota $\mathrm{n}^{\circ} 128$, p. 206.

${ }^{135}$ SETO/EKE, “The criminal”, cit. nota ${ }^{\circ} 128$, pp. 206-208.

${ }^{136}$ Es importante apuntar que Seto afirma recientemente que no es posible encasillar a una persona condenada por un delito de pornografía infantil en la categoría de pedófilo, en los términos en que lo define el registro general de enfermedades psiquiátricas DSM-IV, en tal sentido, la descarga o posesión de escaso material no es un elemento determinante del diagnóstico de un interés por mantener conductas sexuales con menores de edad; el evaluador debe considerar sobre todo el tiempo en que la persona concentró su interés sexual en el material pornográfico (señalando como parámetro válido el superar los 6 meses de interés en las imágenes), para descartar a las personas que tienen motivaciones ocasionales o accidentales en la pornografía infantil. SETO, Michael, "Child pornography use and Internet solicitation in the diagnosis of pedophilia", Archives of Sexual Behavior (2010), pp. 591-593.

${ }^{137}$ SETO/EKE, “The criminal”, cit. nota ${ }^{\circ} 126$, p. 209.
} 
OXMAN, Nicolás. “Aspectos político-criminales y criminológicos de la criminalización de la posesión de pornografía infantil en Estados Unidos de Norteamérica”.

(3,6 años), mientras que 14 individuos $(7,1 \%)$, reincidió en otro delito de pornografía infantil, lo que no significa una variación significativa respecto a la conclusión anterior. ${ }^{138}$

Si desde un punto de vista criminológico no hay un futuro riesgo significativo de lesión a la libertad o indemnidad sexual de los menores, entonces, las normas que castigan este tipo de conductas pasan a ser meras expresiones comunicativas de identificación de la sociedad con la legitimidad del uso del poder penal, en el sentido de que crean la impresión de una mayor intervención por parte del Estado en la lucha contra la criminalidad sexual. Por el contrario, cabe cuestionarse si ello no es sino la demostración de un nueva moral o de un uso inmoral de la ley penal como resultado de un compromiso de orden político y un uso electoral del sistema punitivo. $^{139}$

\section{Conclusiones}

4.1. Se pudo verificar que las razones esgrimidas por Estados Unidos para no ratificar la Convención Internacional de Derechos del niño y formular reservas en cuanto al Protocolo facultativo relativo a la venta de niños, la prostitución infantil y la utilización de niños en la pornografía, creado por la resolución 54/263, del 25 de mayo de 2000, de la Asamblea General de Naciones Unidas, se encuentran plenamente justificadas, desde el momento en que uno de los puntos más controvertidos es, precisamente, la determinación de los límites y alcances del concepto legal de pornografía infantil.

4.2. Fue posible establecer que la regulación de la pornografía infantil se remonta a 1977, lo que constituye el antecedente legal más antiguo que se conoce en este ámbito y, además, se verificó la preocupación, tanto a nivel jurisprudencial como legislativo, por construir una argumentación que permita estimar tal delito como una categoría diferenciada y, por ende, no susceptible de ser tratada sobre la base de los razonamientos dados para regular la pornografía de adultos.

4.3. En efecto, en lo concerniente a la pornografía de adultos se señala que es un asunto que debe solucionarse a partir del reconocimiento de la existencia de un conflicto de intereses entre, por una parte, el derecho constitucionalmente protegido a la libertad de expresión y, por otra parte, el interés de la comunidad por la tutela de sentimientos sociales originados en la concepción, entendimiento y valoración del concepto de "obscenidad".

4.4. Lo anterior, ha sido solucionado otorgando preponderancia a la protección de valores de naturaleza individual, en concreto, el derecho a recibir y expresar opiniones, como también, a difundirlas por cualquier medio, lo que incluye la comercialización y la difusión del material pornográfico de adultos. En consecuencia, los intereses de naturaleza colectiva, derivados de la apreciación de la moral como valor comunitario, no son claramente identificables y adolecen de un extremo subjetivismo que, alejándose de la apreciación que

\footnotetext{
${ }^{138}$ SETO, Michael; EKE, Angela, "Extending the follow-up of child pornography reported by Seto and Eke (2005)", disponible en el sitio web: http://www.indiana.edu/ sexlab/files/pr2006/SetoEke_IASR2006.pdf [visitado el 28.06.2010].

${ }^{139}$ MORILLAS, Análisis dogmático, cit. nota n 2, p. 293. MUÑOZ CONDE, Derecho Penal, cit. nota $n^{\circ} 14$, p. 245 .
} 
cada uno de los jueces pueda tener de la obscenidad, solo puede ser limitado por una regla objetivable, la cual se integra por la concurrencia de dos elementos, a saber, que la obra no tenga un interés literario, artístico, político o científico y, además, se pruebe en el proceso penal la valoración o el reproche de la comunidad. Estándar probatorio que, en la práctica, significó la legalización de todo tipo de pornografía de adultos.

4.5. Por otro lado, la criminalización de la posesión de material pornográfico de adultos es considerada una intromisión intolerable, asimilable, al castigo de los pensamientos, por cuanto se estaría utilizando el derecho para perseguir la sanción de ideas puramente morales que aún no se han expresado en el mundo exterior. Aún más, la persecución penal de tal conducta es estimada como una lesión a la intimidad y libertad individual.

4.6. Ahora bien, ninguno de los argumentos anteriormente expuestos es estimado como válido para solucionar los eventuales conflictos de intereses que puedan existir en torno a la criminalización de la pornografía infantil.

4.7. Fue posible constatar que, tanto a nivel legal como jurisprudencial, no se reconoce ningún tipo de conflicto de intereses en lo referente a la persecución y castigo de la pornografía infantil. Es más, se estima que existe un deber superior del Estado en la protección de la infancia. De este modo, tanto la Corte Suprema como el legislador fundamentan la criminalización de la producción, comercialización y difusión de la pornografía infantil, sobre la base que el material para su elaboración requiere de la realización de un abuso sexual en contra de un menor lesionado en su intimidad y derechos individuales, cuestión que se superpone a toda consideración derivada del reconocimiento a la libertad sexual o de expresión. Además, a la tipificación de las figuras de comercialización y difusión, se les asigna una función de prevención general negativa, ya que la Corte estima que el castigo de tales conductas sirve para disuadir a quienes realizan actos de intermediación entre la producción y el consumo del material. A lo anterior, se le denomina la red de pornografía infantil, concepto que aparece por primera vez, en el año 1985, con ocasión de la solución del caso New York v. Ferber.

4.8. En lo que se refiere a la criminalización de la posesión de pornografía infantil, es necesario distinguir dos tipos de argumentos según la fuente de la cual emanan. De este modo, por un lado, se encuentran los razonamientos esgrimidos a nivel jurisprudencial y, por el otro, la justificación a nivel legislativo. Ambos comparten la idea que, en base al interés superior de la infancia, no es posible recurrir a la traslación de los postulados que pregonan la descriminalización de la posesión de pornografía de adultos, ya que se estima que aquí no se trata de un mero hecho inmoral, sino que de la reproducción constante y la difusión de un abuso o agresión sexual cometida en contra de un menor de edad que carece de la capacidad de autodeterminación en el plano sexual.

4.9. A nivel jurisprudencial la Corte Suprema, desde al caso Osborne v. Ohio, otorga legitimidad al castigo de la posesión de pornografía infantil, sobre la base de una lógica post-consumativa, en el sentido que la lesión o daño ya provocado, lo ha sido porque el poseedor tiene una responsabilidad en el comportamiento de los productores. Su conducta incentiva la producción y realización de otros abusos sexuales. De ahí que la jurisprudencia 
OXMAN, Nicolás. “Aspectos político-criminales y criminológicos de la criminalización de la posesión de pornografía infantil en Estados Unidos de Norteamérica".

entienda necesaria la concurrencia y la prueba de la lesión a un menor real, en oposición a los niños creados por computadora, o a las imágenes que representan jóvenes mayores de edad que aparentan ser niños (caso Ascroft v. Free Speech Coalition).

4.10. Por su parte, el legislador desarrolla una tesis en un plano diferente, donde lo relevante es, únicamente, que la posesión de pornografía conlleva el peligro abstracto de realización de un abuso o agresión sexual en contra de otros menores, es decir, que las personas que almacenan o utilizan ese material para la satisfacción de sus deseos personales tienen un alto grado de probabilidades de transformarse en agresores sexuales. Lo anterior se denomina "ciclo de la pornografía infantil". Sobre la base de tal argumento, todo tipo de pornografía infantil, incluyendo la virtual y la simulada, resultarían ser injustificadas y criminalizables.

4.11. El punto de vista anteriormente expuesto, es compartido por la ciencia penal en Estados Unidos, ya que este tipo de delitos de posesión son considerados como una forma de control discrecional de la sociedad. Particularmente, desde el momento en que se entienden como una manifestación de criminalidad objetiva, por cuanto, la tenencia de material pornográfico infantil puede dar lugar a graves peligros. La doctrina señala que los límites de tipificación de tales delitos están dados por la posibilidad de probar la tenencia con propósitos inocentes, unido al derecho de desvirtuar la prueba del "conocimiento" de la posesión. Limitaciones concretas que encuentran también reconocimiento legal en la regulación de la pornografía infantil, donde se establece el requisito de "conocimiento" y, además, se señalan casos en que puede desvirtuarse la prueba de la posesión con fines delictivos.

4.12. A fin de comprobar la validez de las argumentaciones jurisprudenciales, legales y doctrinales, en torno a la necesidad de criminalización de la posesión de pornografía infantil, resulta necesario recurrir a los estudios científicos de comprobación de riesgo criminal realizados por la criminología.

4.13. En este punto, se evidencia la ausencia de un método específico de determinación de riesgo de reincidencia o de comisión de delitos sexuales futuros para delincuentes condenados por posesión de material pornográfico infantil.

4.14. En efecto, el sistema de medición de riesgos más usado en Estados Unidos es el método actuarial estático, el cual ha sido desarrollado para medir la reincidencia en delincuentes sexuales violentos $y$, por ende, carece de factores o indicadores precisos para la medición de riesgos de comisión futura de delitos sexuales en poseedores de pornografía infantil. Sin embargo, este sistema es estimado como eficaz en la predicción de la reincidencia en delincuentes sexuales sometidos a medidas de seguridad post-delictuales.

4.15. Con todo, los sistemas dinámicos de predicción de riesgos, se muestran frente a los anteriores, como un método orientado no solo a medir científicamente el nivel de peligrosidad, sino que, además, aparecen con una opción de tratamiento. Lo anterior, desde el momento en que se reconocen factores modificables en la personalidad de los delincuentes sexuales, los que podrían cambiar o modificar su conducta, si el sistema es 
Polit. crim. Vol. 6, № 12 (Diciembre 2011), Art. 2, pp. 252 - 294.

[http://www.politicacriminal.cl/Vol_06/n_12/Vol6N12A2.pdf]

utilizado con fines terapéuticos. Este método adolece del mismo defecto que el anterior, porque no ha sido desarrollado para medir el riesgo de comisión futura de delitos sexuales de contacto por parte de personas condenas por posesión de material pornográfico infantil. Es más, el único sistema dinámico específico que existe se encuentra aún en un nivel de evaluación y, por ende, se desconoce su eficacia práctica.

4.16. Frente a la carencia de datos específicos sobre la eficiencia de los métodos actuariales - estáticos o dinámicos- para la comprobación del riesgo que una persona condenada por posesión de material pornográfico infantil cometa un delito sexual, fue necesario recurrir a un estudio estadístico desarrollado en Canadá.

4.17. A partir del estudio anteriormente mencionado, se puede concluir que el riesgo de comisión de un delito sexual de contacto con menores no sería un argumento válido de cara a los datos empíricos. Sin embargo, el nivel de reincidencia genérica en delitos que no involucran contacto sexual, se muestra como elevado. Conclusión arribada no solo por el citado estudio estadístico, sino que, también, por los métodos estáticos y dinámicos de predicción. Entonces, debe ser la sociedad quien se pregunte si está dispuesta a tolerar o asumir los costes de un peligro escaso. Se trata de un asunto que parece estar lejos de decidirse en base a los principios limitadores del poder penal, teniendo en cuenta que se reclama un incremento punitivo para maximizar la neutralización de todo posible ataque a los derechos de la infancia.

\section{BIBLIOGRAFÍA}

ADLER, Amy, "The perverse law of child pornography", Columbia Law Review, t. 101, no $2(2001)$.

AKDENIZ, Yaman, Internet Child Pornography and the Law: National and International Responses, Padstow, Cornwall: TJ International Ltd., 2008.

ANDERSON, Wade, "Comments. Criminalizing "virtual" child pornography under the child pornography prevention act: is it really what it "appears to be"?", University of Richmond Law Review, t. 35 (2001-2002).

ANGLIN, Howard, "The potential liability of federal law-enforcement agents engaged in undercover: Child pornography investigations". New York University Law Review, $t$. 77 (2002).

ARMAGH, Daniel, "Virtual child pornography: criminal conduct or protected speech?", Cardozo Law Review, t. 23 (2001-2002).

BANDURA, Albert, "Análisis del aprendizaje social de la agresión", Modificación de la conducta: Análisis de la agresión y la delincuencia. Biblioteca técnica de psicología, México: Ed. Trillas, 1980.

BARUCH, Jason, "Case comments: constitutional law: permitting virtual child pornography -a first amendment requirement, bad policy, or both? Ashcroft v. Free Speech Coalition, 535 U.S. 234 (2002)", Florida Law Review, t. 55 (2003).

BERGELT, Kelley, "Stimulation by simulation: is there really any difference between actual and virtual child pornography? The Supreme Courts gives child pornographers a new vehicle for satisfaction", Capital University Law Review (2003). 
OXMAN, Nicolás. “Aspectos político-criminales y criminológicos de la criminalización de la posesión de pornografía infantil en Estados Unidos de Norteamérica”.

BOLDOVA PASAMAR, Miguel Ángel, “Comentario al art.189”, en: Diez Ripollés, José Luis; Romeo Casabona, Carlos María (coords.), Comentarios al Código Penal. Parte Especial, t. II, Valencia: Tirant lo Blanch, 2004.

BOYCE, Ronald; DRIPPS, Donald; PERKINS, Rollin, Criminal Law and Procedure, 9a ed. New York: Thomson, 2004.

BOYKIN, Charles, "Ashcroft v. Free Speech Coalition et. al.: Is the child pornography prevention act first amendment friendly, or a virtual disaster?", Southern University Law Review, t. 30 (2003).

CARMONA SALGADO, Concepción, "Lección 10. Delitos contra la libertad sexual (II)", Derecho Penal español: Parte especial. Cobo del Rosal, Manuel (coord.), $2^{\mathrm{a}}$ ed. Madrid: Dykinson, 2005.

CISNEROS, Dannielle, "Virtual Child" Pornography on the Internet: "Virtual" Victim?", Duke Law \& Technology Review, no 23 (2002).

CRAIG, Leam; BROWNE, Kevin; BEECH, Anthony, Assessing risk in sex offenders. A practitioner's guide, Southern Gate, Chichester: Ed., Wiley § Sons Ltda., 2008.

DÍEZ RIPOLLÉS, José Luis, "El Derecho Penal Simbólico y los Efectos de la Pena", Actualidad Penal, nº 1 (2001).

, Exhibicionismo, pornografía y otras conductas sexuales provocadoras: La frontera del derecho penal sexual, Barcelona; Bosch, 1982.

DUBBER, Markus; KELMAN, Mark, American criminal law: Cases, statutes, and comments, New York: Thomson West, 2005.

ETCHEBERRY, Alfredo, Derecho Penal: Parte especial, t. IV, $3^{\text {a }}$ ed. Santiago: Ed. Jurídica de Chile, 2004.

Federal Criminal Code and Rules, New York: West Group, Westlaw, 2000.

FLETCHER, George, Rethinking Criminal Law, 2a ed. New York: Oxford University Press, 2000.

GARRIDO MONTT, Mario, Derecho Penal: Parte especial, t. III, $3^{\text {a }}$ ed. Santiago: Ed. Jurídica de Chile, 2007.

GLADOWSKI, Alison, "Has the computer revolution placed our children in danger? A closer look at the child pornography prevention act of 1996", Cardozo Women's Law Journal, $\mathrm{n}^{\circ}$ 8:21, (2001).

GUGLIELMI, Kelly, "Virtual child pornography as a new category unprotected speech", CommLaw Conspectus, $\mathrm{n}^{\circ} 9$ (2007).

HARCOURT, Bernard, Against prediction: Profiling, policing, and punishing in an actuarial age, Chicago: University of Chicago Press, 2007.

HITT, Jason, "Child pornography and technology: the troubling analysis of United States v. Mohrbacher", University of California Davis Law Review, t. 34, no 4 (2001).

HUSAK, Douglas, Overcriminalization: The limits of the criminal law, New York: Oxford University Press, 2008.

JANUS, Eric; PRENTKLY, Robert, "Forensic use of actuarial risk assessment with sex offender: accuracy, admissibility and accountability”, American Criminal Law Review, $\mathrm{n}^{\circ} 40$ (2003).

KENNEDY, Ryan, "Ashcroft v. Free Speech Coalition: Can we roast the pig without burning the house in regulating "virtual" child pornography?", Akron Law Review, no 379 (2004). 
Polit. crim. Vol. 6, № 12 (Diciembre 2011), Art. 2, pp. 252 - 294.

[http://www.politicacriminal.cl/Vol_06/n_12/Vol6N12A2.pdf]

LABATUT GLENA, Gustavo, Derecho Penal, t. II, $7^{\text {a }}$ ed. Santiago: Ed. Jurídica de Chile, 2007.

LOGAN, Wayne, "Sex offender registration and community notification: past, present, and future", New England Journal on criminal and civil confinement, t. 34, n 3 (2007).

MALESKY, Alvin; ENNIS, Lian; GRESS, Carmen. "Child Pornography and The Internet”, en: Saleh, Fabian; Grudzinkas, Albert; Bradford, Jhon; Brodky, Daniel, (Dirs.), Sex Offenders: identification, risk assessment, treatment, and legal issues, New York: Oxford University Press, 2009.

MARTS, Gary, "Constitutional law-first amendment and freedom of speech-"it's ok- she's a pixel not a pixie: The first amendment protects virtual child pornography. Ashcroft v. Free Speech Coalition. 532 US. 234 (2002)", U.A.L.R. Law Review, no 717 (2003).

MATTEI, Monique; CASEY, Eoghan; McGRATH, Michael, Investigating child exploitation and pornography: The Internet, the law and forensic science, San Diego: Elsevier Academia Press, 2005.

MÉNDEZ RODRÍGUEZ, Cristina, Los Delitos de Peligro y sus Técnicas de Tipificación, Madrid: Universidad Complutense de Madrid, 1993.

MILSTEAD, Virginia, "Ashcroft v. Free Speech Coalition: how can virtual child pornography be banned Ander the first amendment?", Peppidine University Law Review, t. 35 (2003-2004).

MOLAN, Mike/LANSER, Denis; BLOY, Duncan, Principles of Criminal Law, $4^{\mathrm{a}}$ ed. London: Cavendish Publishing Limited, 2000.

MOLINA CANTILLA, René, Delitos de pornografía infantil, Santiago: Ed. Librotecnia, 2008.

MORILLAS FERNÁNDEZ, David, Análisis dogmático y criminológico de los delitos de pornografia infantil: Especial consideración de las modalidades comisivas relacionadas con Internet, Madrid: Dykinson S.L., 2005.

MOTA, Sue Ann, "The U.S. Supreme Court addresses the child pornography prevention act and child online protection act in Ashcroft v. Free Speech Coalition and Ashcroft v. American Civil Liberties Union", Federal Communications Law Journal, t. 55, $\mathrm{n}^{\mathrm{o}}$ 1 (2002).

MUÑOZ CONDE, Francisco, Derecho Penal: Parte especial, $16^{\mathrm{a}}$ ed. Valencia: Tirant lo Blanch, 2007.

ORTS BERENGUER, Enrique; ROIG TORRES, Margarita, "Las recientes reformas a los delitos contra la libertad e indemnidad sexuales", Cuadernos de Política Criminal, $\mathrm{n}^{\circ}$ 84 (2004).

Delitos informáticos y delitos comunes cometidos a través de la informática, Valencia: Tirant lo Blanch, 2001.

ORTS BERENGUER, Enrique; SUÁREZ-MIRA RODRÍGUEZ, Carlos, Los delitos contra la libertad e indemnidad sexuales, Valencia: Tirant lo Blanch, 2001.

PASTOR MUÑOZ, Nuria, Los delitos de posesión y los delitos de estatus: una aproximación político-criminal y dogmática, Barcelona: Atelier, 2005.

PÉREZ RAMÍREZ, Meritxell; REDONDO ILLESCAS, Santiago; MARTÍNEZ GARCÍA, Marian, et. al., "Predicción de riesgo de reincidencia en agresiones sexuales", Psicothema, vol. 20, $\mathrm{n}^{\circ} 2$ (2008).

PEYSAKHOVICH, Sofya, "Virtual child pornography: Why American and British laws at odds with each other", Albany Law Journal of Science \& Technology, t. 14 (2004). 
OXMAN, Nicolás. “Aspectos político-criminales y criminológicos de la criminalización de la posesión de pornografía infantil en Estados Unidos de Norteamérica”.

POLITOFF, Sergio; MATUS, Jean Pierre; RAMÍREZ, Cecilia, Derecho Penal: Parte especial, $2^{\mathrm{a}}$ ed. Santiago: Ed. Jurídica de Chile, 2005.

ROBINSON, Paul, Criminal law: Case studies $\S$ controversies, New York: Wolters Kluwer, 2008.

ROBLES PLANAS, Ricardo, "Sexual Predators. Estrategías y límites al derecho penal de la peligrosidad", InDret: Revista para el Análisis del Derecho, n 4 (2007).

ROCA AGAPITO, Luis, El sistema de sanciones en el Derecho Penal español, Barcelona: Bosch Editor, 2007.

RODRÍGUEZ COLlAO, José Luis, Delitos sexuales, Santiago: Ed. Jurídica de Chile, 2004.

SALEH, Fabian; GRUDZINSKAS, Albert; BRADFORD, Jhon; BRODSKY, Daniel, Sex offenders: Identification, risk assessment, treatment, and legal issue, New York: Oxford University Press, 2009.

SALTZBURG, Stephen; DIAMOND, Jhon, KINPORTS, Kit; MORAWETZ, Thomas, Criminal law: Cases and materials, $2^{\mathrm{a}}$ ed. New York: Lexis Nexis, 2000.

SÁNCHEZ PECAREVIC, Claudio, Delito de almacenamiento de pornografía infantil, Santiago: Ed. Librotecnia, 2010.

SCHMIDT-SANDWICK, Robin, "Constitutional law-freedom of speech: Supreme Court strikes down two provisions of the child pornography prevention act (CPPA), leaving virtual child pornography virtually unregulated. Ashcroft v. Free Speech Coalition, 122 S. Ct. 1389 (2002)", North Dakota Law Review, t. 79 (2003).

SCHOEDER, Freidich-Christian. "La posesión como hecho punible (título original: "Besitz als Straftat")", trad. Polaino-Orts, Miguel, Revista de Derecho Penal y Criminología, Universidad Nacional de Educación a Distancia, ${ }^{\circ} 14$ (2004).

SEMAN, Dean, "United States v. Corp: Where to draw the interstate line on Congress' commerce clause authority to regulate intrastate possession of child pornography", Villanova S. § Ent. Law Journal, t. 9 (2002).

SETO, Michael, "Child pornography use and Internet solicitation in the diagnosis of pedophilia", Archives of Sexual Behavior (2010).

SETO, Michael; EKE, Angela, "Extending the follow-up of child pornography reported by Seto and Eke (2005)", disponible en el sitio web: http://www.indiana.edu/ $\sim$ sexlab/files/pr2006/SetoEke IASR2006.pdf.

, "The criminal histories and later offending of child pornography offenders", Sexual Abuse: A Journal of Research and Treatment, $t$. 17, $\mathrm{n}^{\circ} 2$ (2005).

SHIRAZI, Emanuel, "How to constitutionally protect against virtual child pornography", Hastings Communication and Entertainment Law Journal, t. 35 (2003).

SHUSTER, Lyndall, "Regulating virtual child pornography in the wake of Ashcroft v. Free speech coalition”, Denver University Law Review, $t$. 80, n 2 (2002).

SIEG, Robert, "Attempted possession of child pornography- a proposed approach for criminalizing possession of child pornographic images of unknown origin", The University of Toledo Law Review, $t$. 36, $\mathrm{n}^{\circ} 2$ (2005).

SILVA SÁNCHEZ, Jesús María, "El retorno a la inocuización. El caso de las reacciones jurídico-penales a los delincuentes sexuales violentos", en: Arroyo Zapatero, Luis; Verdugo Gómez de la Torre, Ignacio (Dirs.), Homenaje al Dr. Marino Barbero 
Polit. crim. Vol. 6, № 12 (Diciembre 2011), Art. 2, pp. 252 - 294.

[http://www.politicacriminal.cl/Vol_06/n_12/Vol6N12A2.pdf]

Santos in memoriam, t. I, Castilla La Mancha: Ed. Universidad Castilla la Mancha, 2001. ,Aproximación al Derecho Penal Contemporáneo", Barcelona: Editorial Bosch, 2002.

SLOCUM, Brian, "Virtual child pornography does it mean the end the child pornography exception to the first amendment?", Albany Law Journal of Science \& Technology, Vol. 14 (2004).

SMITH, Tom, "The use of public opinion data by the Attorney General's Commission on Pornography", American Association for Public Opinion Research, The Public Opinion Quarterly, t. 51, $\mathrm{n}^{\circ} 2$ (1987)

TAMARIT SUMALLA, Josep María, La protección penal del menor frente al abuso y explotación sexual: Análisis de las reformas penales de 1999 en materia de abusos sexuales, prostitución y pornografía de menores, Navarra: Aranzadi Editorial, 2000.

United States Supreme Court, Ashcroft v. Free Speech Coalition, (00-795) 535 U.S. 234 (2002), disponible en el sitio web: http://www.law.cornell.edu/supct/html/00795.ZS.html

United States Supreme Court, Miller v. California, 413, U.S. 15 (1973), disponible en el sitio

web: http://www.law.cornell.edu/supct/html/historics/USSC_CR_0413_0015_ZS.html

United States Supreme Court, New York v. Ferber, 458 U.S. 747 (1982), disponible en el sitio web: http://www.law.cornell.edu/supct/html/historics/USSC CR 04580747 ZS.html

United States Supreme Court, Osborne v. Ohio, 495 U.S. 103 (1990), disponible en el sitio web: http://www.law.cornell.edu/supct/html/historics/USSC_CR 04950103 ZS.html

United States Supreme Court, Stanley v. Georgia, 394 U.S. 557 (1969), disponible en el sitio web: http://www.law.cornell.edu/supct/html/historics/USSC CR 03940557 ZS.html

WATANABE, Jacqueline, "Real Problems, virtual solutions: the (still) uncertain future of virtual child pornography legislation", Journal of Technology Law $\S$ Policy, t. 10 (2005).

WEGNER, Matthew, “Teaching old dogs new tricks: Why traditional free speech doctrine supports anti-child-pornography regulations in virtual reality", Minnesota Law Review, t. 85, $\mathrm{n}^{\circ} 6$ (2001).

WEISS, Karen, "But she was only a child. That is obscene!" the unconstitutionality of past and present attempts to ban virtual child pornography and the obscenity alternative", George Washington Law Review, t. 70, $\mathrm{n}^{\circ} 1$ (2002). 